\title{
Catching Geomorphological Response to Volcanic Activity on Steep Slope Volcanoes Using Multi-Platform Remote Sensing
}

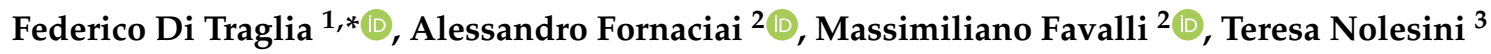 \\ and Nicola Casagli ${ }^{1}$ (D) \\ 1 Dipartimento di Scienze della Terra, Università degli Studi di Firenze, Via La Pira 4, 50121 Firenze, Italy; \\ nicola.casagli@unifi.it \\ 2 Istituto Nazionale di Geofisica e Vulcanologia, Sezione di Pisa, Via Cesare Battisti, 53 - 56125 Pisa, 56125 Pisa, \\ Italy; alessandro.fornaciai@ingv.it (A.F.); massimiliano.favalli@ingv.it (M.F.) \\ 3 Centro per la Protezione Civile, Università degli Studi di Firenze, Piazza San Marco 4, 50121 Firenze, Italy; \\ teresa.nolesini@unifi.it \\ * Correspondence: federico.ditraglia@unifi.it
}

Received: 22 December 2019; Accepted: 28 January 2020; Published: 30 January 2020

check for updates

\begin{abstract}
The geomorphological evolution of the volcanic Island of Stromboli (Italy) between July 2010 and June 2019 has been reconstructed by using multi-temporal, multi-platform remote sensing data. Digital elevation models (DEMs) from PLÉIADES-1 tri-stereo images and from Light Detection and Ranging (LiDAR) acquisitions allowed for topographic changes estimation. Data were comprised of high-spatial-resolution (QUICKBIRD) and moderate spatial resolution (SENTINEL-2) satellite images that allowed for the mapping of areas that were affected by major lithological and morphological changes. PLÉIADES tri-stereo and LiDAR DEMs have been quantitatively and qualitatively compared and, although there are artefacts in the smaller structures (e.g., ridges and valleys), there is still a clear consistency between the two DEMs for the larger structures (as the main valleys and ridges). The period between July 2010 and May 2012 showed only minor changes consisting of volcanoclastic sedimentation and some overflows outside the crater. Otherwise, between May 2012 and May 2017, large topographic changes occurred that were related to the emplacement of the 2014 lava flow in the NE part of the Sciara del Fuoco and to the accumulation of a volcaniclastic wedge in the central part of the Sciara del Fuoco. Between 2017 and 2019, minor changes were again detected due to small accumulation next to the crater terrace and the erosion in lower Sciara del Fuoco.
\end{abstract}

Keywords: LiDAR DEM; PLÉIADES tri-stereo DEM; topographic change detection; remote sensing volcanoes; slope dynamics; volcanic geomorphology

\section{Introduction}

Steep volcano flanks are geomorphological systems that are highly responsive to both exogenous dynamics and endogenous forcing [1]. While the external (gravitational) processes lead to a shift of material from steeper slopes to areas with lower gradients (erosion of loose deposits and rockfall of lavas/welded material), magmatic and tectonic activity can have either constructional (accumulation) or a destructive effects (triggering moderate to large-scale mass-wasting) [2]. Optical and synthetic aperture radar (SAR) sensors have often been used to maps areas that have been affected by lithological and morphological changes, i.e., to identify areas that have been impacted by eruptive and post-eruptive (landslides or floods) phenomena [3-23], whereas multi-temporal digital elevation models (DEMs) have allowed for the quantification of topographic changes [24-42]. 
In this work, geomorphological variations on high-gradient volcano flanks in response to shifts in volcanic activity have been identified by means of remote sensing techniques. The Sciara del Fuoco (SdF) depression on the island of Stromboli (Italy) was studied, as it is the optimal test-site for monitoring the effect of volcanic eruption on steep-slope volcano flank because (i) it is affected by persistent volcanic activity, (ii) it is prone to mass-wasting phenomena, and (iii) it is one of the best studied and, among all, most monitored volcano sites on Earth, providing exceptional validation data and ground-truth constraints. A large set of multi-temporal data of the SdF was acquired, including Light Detection and Ranging (LiDAR) data, tri-stereo PLÉIADES-1 imagery, high-spatial-resolution (HSR) optical imagery (QUICKBIRD and PLÉIADES-1), and moderate spatial resolution (MSR) SENTINEL-2 multi-spectral instruments (MSI) imagery. Multi-temporal data permitted the mapping of areas affected by major lithological and morphological changes, as well as the volumes of deposited/eroded material. Moreover, the results of this study were strengthened by the integration of previous geomorphological reconstructions $[23,28,41,43,44]$. The results led to the identification of topographical variations and geomorphological processes that occurred in response to the variation in eruptive intensity.

\section{Materials and Methods}

\subsection{Study Area}

The $916 \mathrm{~m}$-high Stromboli Island is the emerged portion of a $3000 \mathrm{~m}$-high stratovolcano located in the Tyrrhenian Sea off the southern coast of Italy (Figure 1). The volcano experienced several large mass-wasting phenomena, which formed two scars, one on its NW flank (Sciara del Fuoco; SdF) and the other one on its SE flank, with a consequence bilateral flank instability [45-47]. The SdF depression is filled with volcaniclastic deposits and lavas [48-50] that are emitted from a summit crater terrace located at $\approx 750 \mathrm{~m}$ a.s.l., and from ephemeral vents within the SdF [51]. The distinctive persistent Strombolian activity is characterized by intermittent explosions from three vent areas (NE, SW and central) that are located in a summit crater terrace [52]. This activity, showing intensity and frequency fluctuations over time, is often punctuated by lava overflows from the crater terrace [44], and/or by flank eruptions, with the outpouring of lava flows from ephemeral vents [32]. Recent eruptive activity and slope instability events are summarized in Table 1 . The last flank eruption, characterized by lava emission from an ephemeral vent located at $650 \mathrm{~m}$ a.s.1., started on 7 August 2014, was preceded by two months of increased Strombolian activity and several lava overflows from the craters, and lasted until 13 November 2014 [41,53-60]. Both in December 2017 and 2018, the eruptive activity increased (spattering and overflows), mainly in the North-Eastern Crater (NEC) area, which led to the growth of the NEC cone outside of the crater terrace [1,2]. This activity was related to frequent, small scale, instability phenomena, such as rockfalls and gravel slides that evolved into gravel flows [2]. 


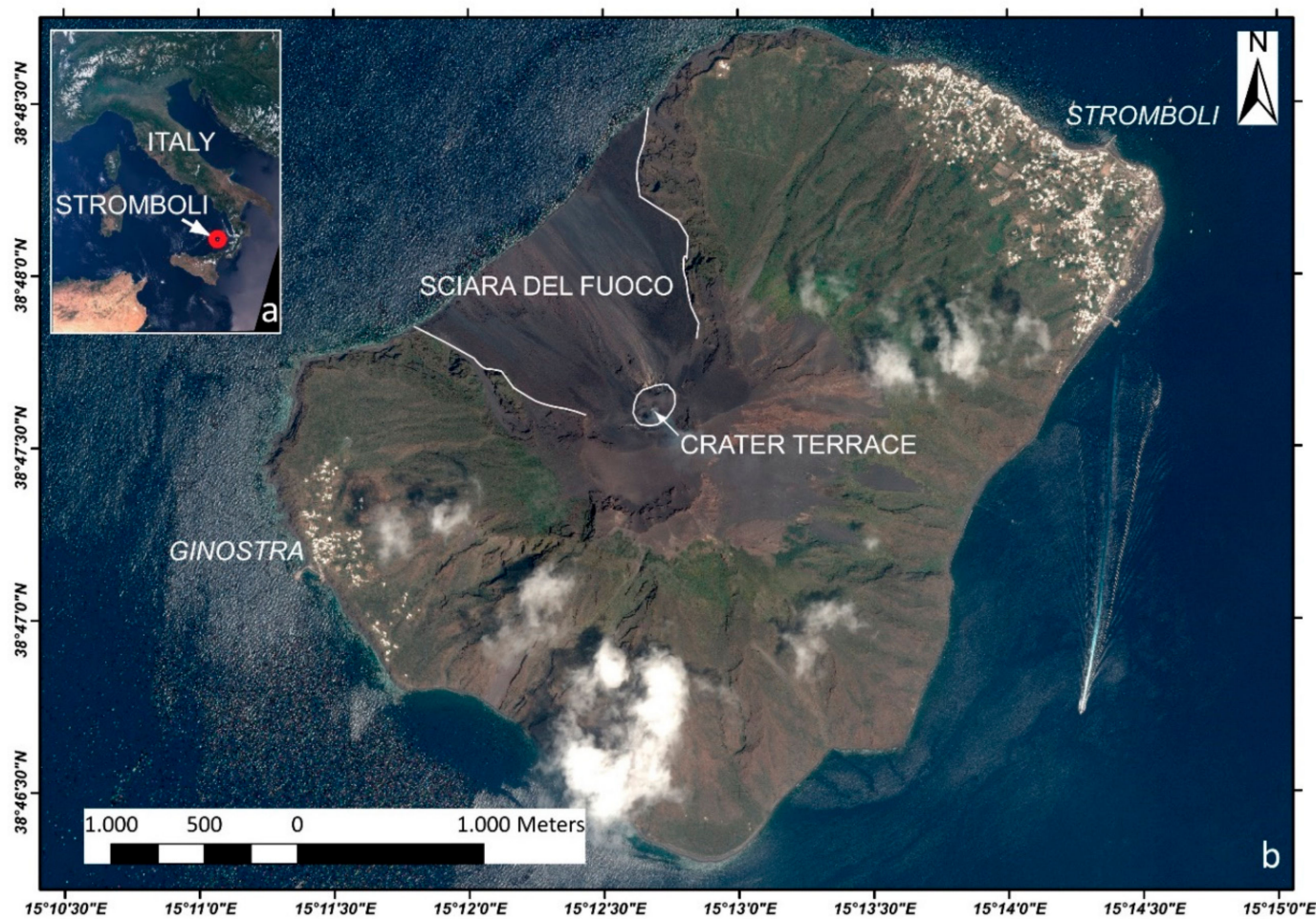

Figure 1. (a) Geographic location of the Aeolian Islands (image collected by SENTINEL-3 on 19 July 2018); (b) PLÉIADES-1B image (1 September 2018) of Stromboli Island. The main geographic and geological features are reported.

Table 1. Summary of the eruptive activity at Stromboli volcano from 2010 to 2019.

\begin{tabular}{|c|c|c|c|}
\hline Date & Eruptive Activity & Slope Processes & References \\
\hline March 2010 & $\begin{array}{l}\text { Strong explosive event (10 March 2010), } \\
\text { ejecta outside the crater, and } \\
\text { rheomorphic lava flows to the NEC }\end{array}$ & & {$[44,53]$} \\
\hline May 2010-June 2010 & $\begin{array}{l}\text { Strong explosive events, rheomorphic } \\
\text { lava flows and intracrateric lava flows }\end{array}$ & & {$[44,53]$} \\
\hline October 2010 & $\begin{array}{l}\text { Intracrater lava flow from the SWC vent } \\
\qquad(19-26 \text { October 2010) }\end{array}$ & & {$[44,53]$} \\
\hline December 2010-January 2011 & $\begin{array}{c}\text { Strong explosive events, intense } \\
\text { spattering and overflows from the SWC }\end{array}$ & & {$[44,53]$} \\
\hline March 2011 & $\begin{array}{c}\text { Strong explosive event (4 March 2011) } \\
\text { from the SWC }\end{array}$ & & {$[44,53]$} \\
\hline June 2011-September 2011 & $\begin{array}{c}\text { Strong explosive events and two } \\
\text { overflows }\end{array}$ & & {$[44,53-55]$} \\
\hline February-March 2012 & $\begin{array}{l}\text { Strong explosive events (15-16 February } \\
\text { 2012, } 6 \text { March 2012) }\end{array}$ & & {$[44,55]$} \\
\hline July 2012-August 2012 & $\begin{array}{l}\text { Major explosions, intense spattering } \\
\text { and overflows }\end{array}$ & & {$[44]$} \\
\hline December 2012-June 2013 & $\begin{array}{c}\text { Several lava overflows, strong explosive } \\
\text { events and intense spatter activity, as } \\
\text { well as a high displacement rate in the } \\
\text { crater terrace }\end{array}$ & $\begin{array}{l}\text { Crater-wall rock slide (12 } \\
\text { January 2013), frequent } \\
\text { rockfall and gravel flows } \\
\text { during lava overflows }\end{array}$ & {$[44,55,56]$} \\
\hline December 2013-March 2014 & $\begin{array}{l}\text { Strong explosive events, intense } \\
\text { spattering, and anomalous degassing }\end{array}$ & & {$[58,59]$} \\
\hline
\end{tabular}


Table 1. Cont.

\begin{tabular}{|c|c|c|c|}
\hline Date & Eruptive Activity & Slope Processes & References \\
\hline June 2014-November 2014 & $\begin{array}{l}\text { Several lava overflows, strong explosive } \\
\text { events, intense spatter activity, opening } \\
\text { of an ephemeral vent at } 650 \mathrm{~m} \text { a.s.l. (100 } \\
\text { below the NEC), and lava flow lasting } \\
3 \text { months }\end{array}$ & $\begin{array}{l}\text { Frequent rockfall and gravel } \\
\text { flows during lava overflows } \\
\text { and sliding of the NEC debris } \\
\text { talus (7 August 2014) }\end{array}$ & {$[41,57-59]$} \\
\hline November 2014-September 2016 & & $\begin{array}{l}\text { Rockfall and gravel flows } \\
\text { affecting the } 2014 \text { lava field }\end{array}$ & {$[2,61]$} \\
\hline December 2017-January 2018 & $\begin{array}{l}\text { Intense spatter activity and a lava } \\
\text { overflow }\end{array}$ & $\begin{array}{l}\text { Frequent rockfall and gravel } \\
\text { flows during spatter activity }\end{array}$ & {$[2,61]$} \\
\hline December 2018-January 2019 & Intense spatter activity & $\begin{array}{l}\text { Frequent rockfall and gravel } \\
\text { flows during spatter activity }\end{array}$ & This study \\
\hline
\end{tabular}

Slope instability phenomena at Stromboli are classified, on the base of their size and movement, into three types [2,62]: (1) "deep-seated gravitational slope deformations" evolving to "rock or debris avalanches" from the SdF (volumes $>10^{6} \mathrm{~m}^{3}$ ); (2) "rock (rotational or planar) slides" evolving to "rock avalanches" from the $\mathrm{SdF}$ (volumes $\approx 10^{6} \mathrm{~m}^{3}$ ); and (3) "rock falls" or "gravel/debris slides" evolving to "gravel/debris flows" (volumes $\approx 10^{5} \mathrm{~m}^{3}$ ). The greatest hazard associated with large-scale landslides (type-1) at Stromboli is their ability to generate tsunamis, whose effects can propagate far away from the source areas $[63,64]$.

\subsection{Geomorphological Mapping}

In the last few decades, different remote sensing techniques have been used to catch environmental responses to volcanic activity (Table 2). Here, the geomorphological mapping of the SdF was based on the integration of field surveys, multi-temporal, satellite-borne HSR optical imagery, morphometric analysis and topographic change detection (TCD). The topographic data used were four different DEMs that were derived from 2010 and 2012 LiDAR data and 2017 and 2019 PLÉIADES-1 images. The HSR-orthorectified imagery dataset (Table 3 and Figure 2) comprised 2 QUICKBIRD images (21 March 2008 and 23 September 2012) and 4 PLÉIADES-1 images (6 May 2016, 26 May 2017; 28 August 2017, 1 September 2018).

Table 2. Previous remote sensing-based studies on the geomorphological response to volcanic eruptions.

\begin{tabular}{|c|c|c|}
\hline Volcano & Techniques & References \\
\hline Casita (Nicaragua) & Optical images change detection-SAR amplitude change detection & 6 \\
\hline Pinatubo (Philippines) & Optical images change detection & 7 \\
\hline Merapi (Indonesia) & Optical image object-oriented classification & 18 \\
\hline Merapi (Indonesia) & Optical images change detection & 16 \\
\hline Merapi (Indonesia) & Optical image change detection-Topographic change detection & 18 \\
\hline Merapi (Indonesia) & Polarization SAR analysis & 17 \\
\hline Semeru (Indonesia) & Optical image object-oriented classification & 15 \\
\hline Stromboli (Italy) & Topographic change detection (photogrammetry) & 25,27 \\
\hline Stromboli (Italy) & Topographic change detection (photogrammetry) & 28 \\
\hline Stromboli (Italy) & Topographic change detection (PLÉIADES tri-stereo) & 41 \\
\hline Stromboli (Italy) & SAR amplitude change detection-SAR amplitude texture analysis & 23 \\
\hline
\end{tabular}


Table 2. Cont

\begin{tabular}{ccc}
\hline Volcano & Techniques & References \\
\hline Etna (Italy) & Topographic change detection (LiDAR) & 24 \\
\hline Etna (Italy) & Topographic change detection (LiDAR) & 30 \\
\hline Etna (Italy) & Topographic change detection (LiDAR) & 31 \\
\hline Etna (Italy) & Topographic change detection (LiDAR-photogrammetry) & 34 \\
\hline Etna (Italy) & Topographic change detection (LiDAR) & 33 \\
\hline Fogo (Cape Verde) & Topographic change detection (TANDEM-X/PLÉIADES tri-stereo) & 35 \\
\hline Fogo (Cape Verde) & Topographic change detection (photogrammetry-TLS) & 39 \\
\hline Soufriere Hills (Montserrat) & SAR amplitude change detection & 11 \\
\hline Soufriere Hills (Montserrat) & SAR amplitude change detection-SAR topographic change detection & 19 \\
\hline Arenal (Costa Rica) & SAR amplitude change detection & 14 \\
\hline Santiaguito (Guatemala) & SAR topographic change detection & 13 \\
\hline El Renventador (Ecuador) & SAR topographic change detection & 40 \\
\hline El Renventador (Ecuador) & SAR amplitude change detection & 20 \\
\hline Cotopaxi (Ecuador) & SAR amplitude change detection & 22 \\
\hline Hekla (Iceland) & Topographic change detection (photogrammetry) & 42 \\
\hline Kilauea (USA) & SAR coherence & 12 \\
\hline Mount St. Helens (USA) & SAR amplitude change detection & 21 \\
\hline
\end{tabular}

Table 3. Technical characteristics of satellite sensor and high-spatial-resolution (HSR) images used for this study.

\begin{tabular}{ccc}
\hline & QUICKBIRD & PLÉIADES \\
\hline Acquisition date & 6 May 2016 \\
& 26 May 2017 \\
& 23 September 2012 & 28 August 2017 \\
1 September 2018 & 3 June 2019 \\
\hline Spatial resolution PAN (m) & $0.7 \times 0.7$ & $0.5 \times 0.5$ \\
\hline Spatial resolution MS (m) & $2.5 \times 2.5$ & $1 \times 1$ \\
\hline Cloud coverage (\%) & $<10$ & $<5$ \\
\hline Blue & Spectral resolution (nm) & $450-550$ \\
\hline Green & $450-520$ & $490-610$ \\
\hline Red & $520-600$ & $600-720$ \\
\hline Near infrared & $630-690$ & $750-920$ \\
\hline
\end{tabular}



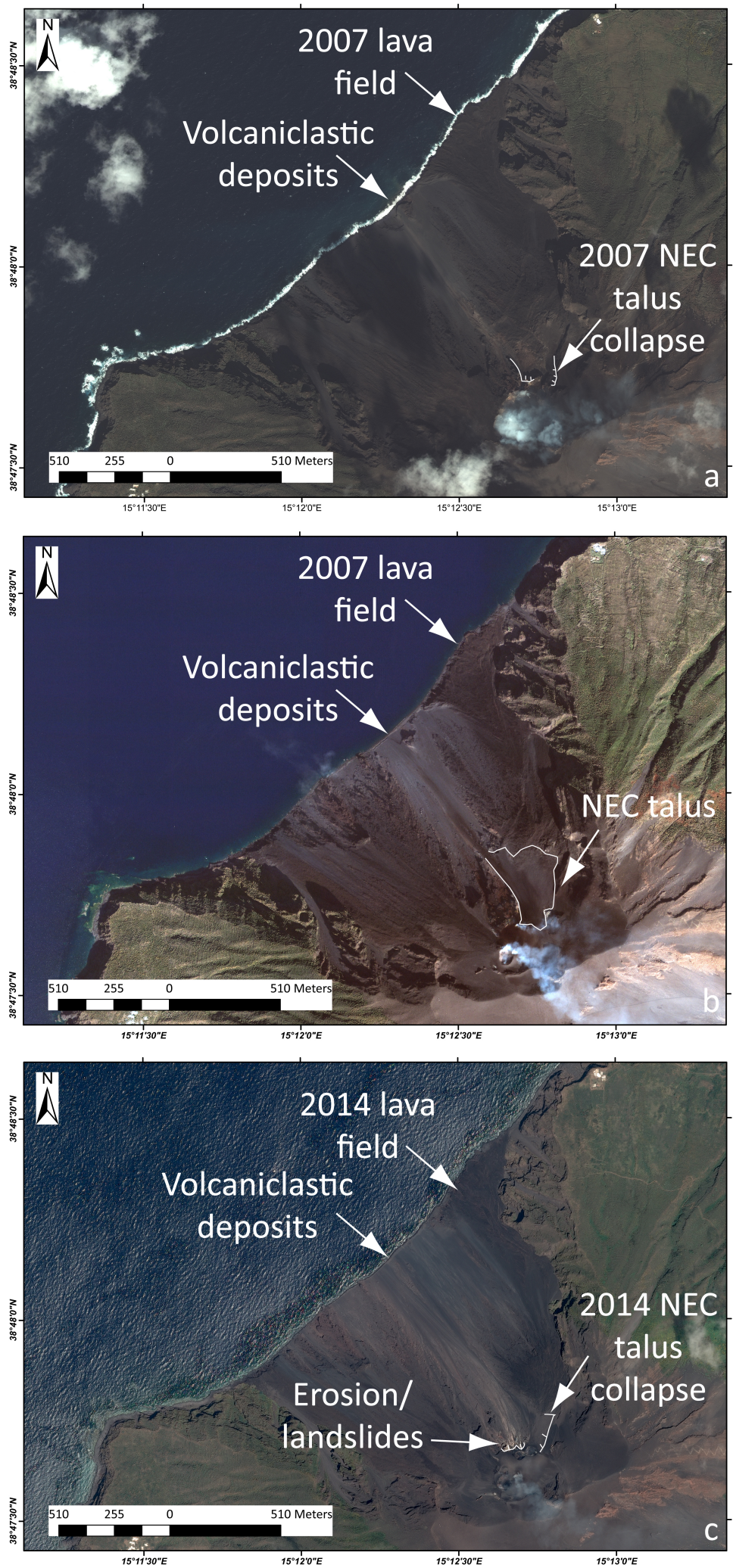

Figure 2. HSR optical images of the Sciara del Fuoco (SdF) and crater terrace. QUICKBIRD images collected on (a) 21 March 2008 and (b) 23 September 2012; (c) PLÉIADES images collected on 13 June 2019. 
Moreover, multi-temporal SENTINEL-2 MSI images were used to constrain the main geomorphological events in a higher temporal resolution (Table 4 and Figure 3). The spatial resolution of SENTINEL-2 MSI bands is 10-60 m and has a coverage between -56 and +84 degrees latitude with a $290 \mathrm{~km}$ swath width. The minimum revisit time at the equator is 5 days, which increases a when maximum cloud cover is set (max. $=5 \%$ for this study). Several band combination and ratios have been used to enhance contrasts between features, as well as to reduce the variations in topographic illumination.

Table 4. Technical characteristics of the moderate spatial resolution (MSR) multi-spectral SENTINEL-2 sensor and images used for this study.

\begin{tabular}{|c|c|c|c|c|c|}
\hline \multirow{2}{*}{$\begin{array}{c}\text { Spatial } \\
\text { Resolution (m) }\end{array}$} & \multirow[b]{2}{*}{ Band Number } & \multicolumn{2}{|c|}{ SENTINEL-2A } & \multicolumn{2}{|c|}{ SENTINEL-2B } \\
\hline & & $\begin{array}{c}\text { Central } \\
\text { Wavelength }(\mathrm{nm})\end{array}$ & $\begin{array}{c}\text { Bandwidth } \\
(\mathrm{nm})\end{array}$ & $\begin{array}{c}\text { Central } \\
\text { Wavelength }(\mathrm{nm})\end{array}$ & $\begin{array}{l}\text { Bandwidth } \\
\text { (nm) }\end{array}$ \\
\hline \multirow{4}{*}{10} & 2 & 496.6 & 98 & 492.1 & 98 \\
\hline & 3 & 560.0 & 45 & 559 & 46 \\
\hline & 4 & 664.5 & 38 & 665 & 39 \\
\hline & 8 & 835.1 & 145 & 833 & 133 \\
\hline \multirow{6}{*}{20} & 5 & 703.9 & 19 & 703.8 & 20 \\
\hline & 6 & 740.2 & 18 & 739.1 & 18 \\
\hline & 7 & 782.5 & 28 & 779.7 & 28 \\
\hline & $8 a$ & 864.8 & 33 & 864 & 32 \\
\hline & 11 & 1613.7 & 143 & 1610.4 & 141 \\
\hline & 12 & 2202.4 & 242 & 2185.7 & 238 \\
\hline \multirow{3}{*}{60} & 1 & 443.9 & 27 & 442.3 & 45 \\
\hline & 9 & 945.0 & 26 & 943.2 & 27 \\
\hline & 10 & 1373.5 & 75 & 1376.9 & 76 \\
\hline
\end{tabular}



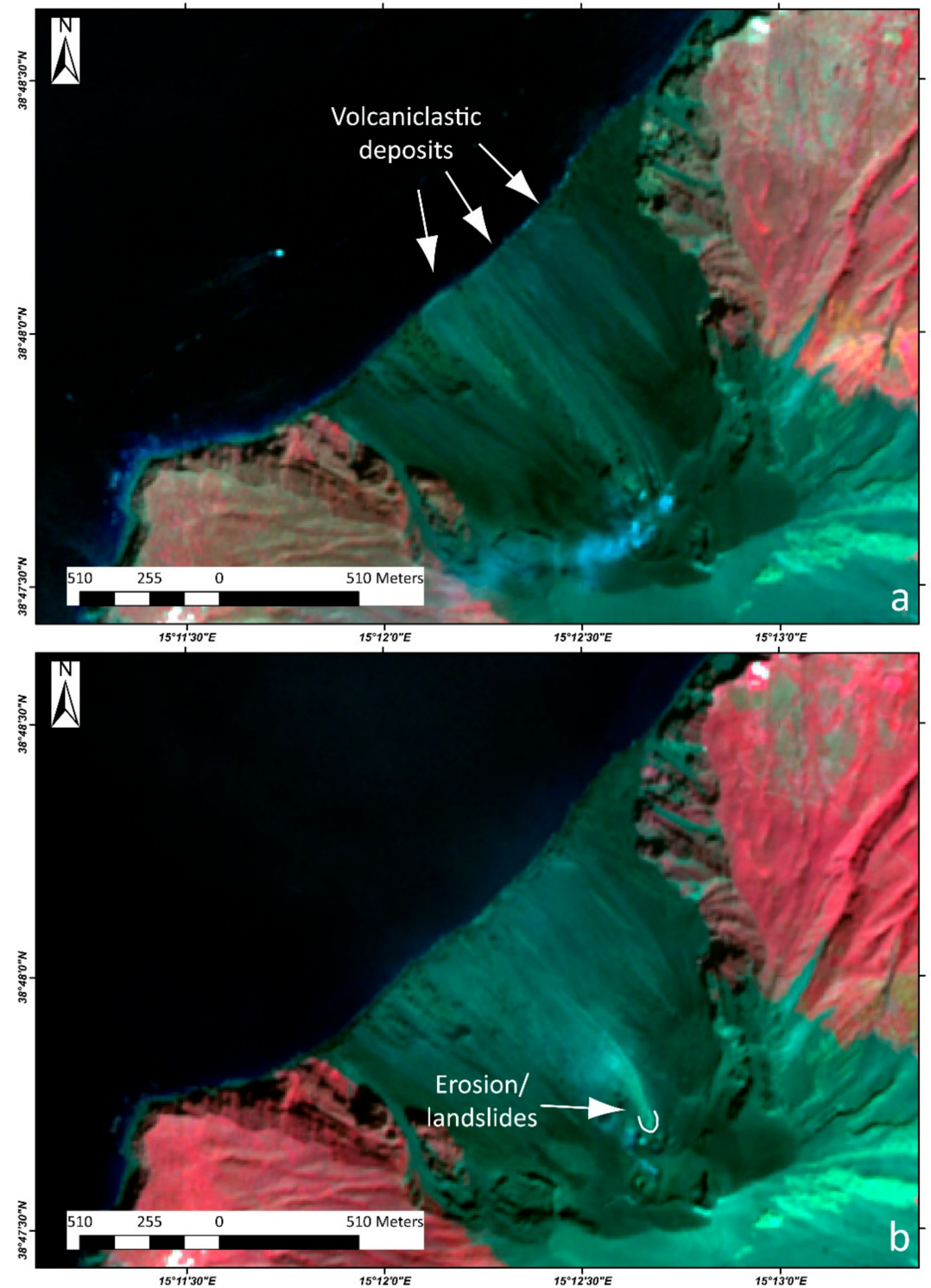

Figure 3. MSR SENTINEL-2 multi-spectral instruments (MSI) of Stromboli Island (based on bands 2, 4, and 3) collected on (a) 26 August 2017, showing volcaniclastic accumulation along the shoreline, and (b) 3 April 2018, showing the area affected by erosion/landslides around the crater terrace.

\subsection{Topographic Source Data and Methods}

The detection of topographic changes measured by differentiating pre-, sin-, and post-eruptive DEMs is nowadays considered the most suitable method to accurately quantify the volume of material that is emplaced or removed during volcanic eruptions (Table 1). In this study, the topographic change detection of Stromboli Island from 2010 to 2019 was performed by using DEMs that were derived from data that were acquired by airborne LiDAR data and PLÉIADES-1 tri-stereo satellite imagery.

Airborne LiDAR is an active remote sensing system that integrates data from a laser ranging and scanning unit and a position and orientation system (POS), that is generally mounted on a small aircraft, and that is used to acquire a dense cloud of points with known coordinates of the imaged surface. The point cloud is then generally used to generate an HSR $(1 \mathrm{~m})$ DEM. In this work, the first LiDAR data of the Stromboli volcano were acquired on 22 July 2010 by using an Optech Airborne Laser Terrain Mapper (ALTM) GEMINI laser altimeter (http://optech.on.ca). The nominal instrumental planimetric and vertical accuracies were in the ranges of $0.8-1.35$ and $0.25-0.35 \mathrm{~m}$, respectively. The point cloud had a mean point density of $1 \mathrm{pts} / \mathrm{m}^{2}$, which allowed us to generate a $1-\mathrm{m}$ resolution 
DEM. The second LiDAR-DEM was obtained by elaborating the 3D point cloud that was acquired during an airborne survey that was carried out on May 2012. The data were acquired by using the Leica ADS80 sensor, which has instrumental vertical and horizontal accuracy of $0.10-0.20$ and $0.25 \mathrm{~m}$, respectively [41,65]. The acquired point cloud had a mean point density of $8 \mathrm{pt} / \mathrm{m}^{2}$.

The 2017 and 2019 DEMs were derived from the tri-stereo optical imagery that was acquired by the PLÉIADES-1 satellite. The PLÉIADES-1 constellation is composed by two satellites, PLÉIADES-1A (PHR1A) and PLÉIADES-1B (PHR1B). These satellites can sense three or more synchronous images of the same area, with an angle variable between $\sim 6^{\circ}$ and $\sim 28^{\circ}$. The stereoscopic triplet is composed of three nearly simultaneously acquired images, one backward looking, one forward looking, and a third near-nadir image $[35,41,66]$. The tri-stereo images of this work were $100 \%$ cloud free, but the presence of smoke emitted that was by the vents prevented the correct acquisition of the crater terrace. The total areal acquired was $58 \mathrm{~km}^{2}$. This acquisition mode permitted the obtainment of a DEM through the photogrammetric processing of the three stereo images (tri-stereo mode). The dataset also comprised panchromatic and multispectral very high resolution (VHR) optical imagery with spatial resolutions of 0.5 and $2 \mathrm{~m}$, respectively. To assess the accuracy of the heights and their horizontal position in the PLÉIADES-1 DEM, ground control points (GCPs) were collected on the map database (cartographic XY standard deviation: $0.15 \mathrm{~m}$ ). Tie points were automatically collected in the images (Table 5 and Supplementary Materials). A block adjustment including all the satellite scenes was performed. The block adjustment was validated when the following accuracy was achieved: (i) a pixel xy bias smaller than 0.3 pixels; (ii) a pixel xy standard deviation smaller than 0.3 pixels; and (iii) a pixel xy maximum smaller than 2 pixels.

Table 5. Results of the PLÉIADES images adjustment.

\begin{tabular}{|c|c|c|c|c|c|c|c|c|c|}
\hline \multicolumn{10}{|c|}{ Images Points Residuals (pixels) } \\
\hline \multirow[t]{2}{*}{ DATE } & \multicolumn{3}{|c|}{6 May 2016} & \multicolumn{3}{|c|}{26 May 2017} & \multicolumn{3}{|c|}{28 August 2017} \\
\hline & \multicolumn{3}{|c|}{$\mathrm{Y}$} & $x$ & \multicolumn{2}{|l|}{$\mathrm{Y}$} & $x$ & \multicolumn{2}{|l|}{$\mathrm{Y}$} \\
\hline XY BIASS & -0.0003 & \multicolumn{2}{|l|}{0.0002} & -0.0006 & \multicolumn{2}{|l|}{0.0006} & 0.003 & \multicolumn{2}{|l|}{0.0015} \\
\hline XY STANDARD DEVIATION & 0.0834 & \multicolumn{2}{|l|}{0.0857} & 0.0921 & \multicolumn{2}{|l|}{0.0892} & 0.1419 & \multicolumn{2}{|l|}{0.1227} \\
\hline XY MAX & 0.2694 & \multicolumn{2}{|l|}{0.2696} & 0.2198 & \multicolumn{2}{|l|}{0.2440} & 0.3218 & \multicolumn{2}{|l|}{0.3472} \\
\hline \multicolumn{10}{|c|}{ Control Points Residuals (m) } \\
\hline DATE & \multicolumn{3}{|c|}{6 May 2016} & \multicolumn{3}{|c|}{26 May 2017} & \multicolumn{3}{|c|}{28 August 2017} \\
\hline & $x$ & $\mathrm{Y}$ & $\mathrm{Z}$ & $x$ & Y & $\mathrm{Z}$ & $x$ & Y & $\mathrm{Z}$ \\
\hline XYZ BIASS & 0.7114 & -0.1244 & 0.6461 & 0.2973 & -0.2681 & 0.0525 & 0.1605 & -0.0949 & 0.0042 \\
\hline $\begin{array}{l}\text { XYZ STANDARD } \\
\text { DEVIATION }\end{array}$ & 0.7057 & 0.5371 & 2.5056 & 0.2289 & 0.0827 & 1.5554 & 0.1914 & 0.1499 & 0.3856 \\
\hline XYZ MAX & 1.5439 & 1.1412 & 4.9776 & 0.5758 & 0.3909 & 3,0559 & 0.4578 & 0.2970 & 0.6948 \\
\hline \multicolumn{10}{|c|}{ Images Points Residuals (pixels) } \\
\hline DATE & \multicolumn{3}{|c|}{1 September 2018} & \multicolumn{4}{|c|}{13 June 2019} & & \\
\hline & $x$ & $\mathrm{Y}$ & $x$ & $\mathrm{Y}$ & $x$ & \multicolumn{2}{|c|}{$\mathrm{Y}$} & & \\
\hline XY BIASS & 0.0002 & 0.0009 & 0.0002 & 0.0009 & 0.0002 & \multicolumn{2}{|c|}{0.0009} & & \\
\hline XY STANDARD DEVIATION & 0.1341 & 0.1297 & 0.1341 & 0.1297 & 0.1341 & \multicolumn{2}{|c|}{0.1297} & & \\
\hline XY MAX & 0.4045 & 0.3841 & 0.4045 & 0.3841 & 0.4045 & \multicolumn{2}{|c|}{0.3841} & & \\
\hline \multicolumn{10}{|c|}{ Control Points Residuals (m) } \\
\hline DATE & \multicolumn{3}{|c|}{1 September 2018} & \multicolumn{4}{|c|}{13 June 2019} & & \\
\hline & $x$ & $\mathrm{Y}$ & $x$ & $\mathrm{Y}$ & $x$ & & & & \\
\hline XYZ BIASS & 0.0099 & -0.0049 & 0.0099 & -0.0049 & 0.0099 & & & & \\
\hline $\begin{array}{l}\text { XYZ STANDARD } \\
\text { DEVIATION }\end{array}$ & 0.193792 & 0.1519 & 0.193792 & 0.1519 & 0.193792 & & & & \\
\hline XYZ MAX & 0.374875 & 0.2606 & 0.374875 & 0.2606 & 0.374875 & & & & \\
\hline
\end{tabular}




\subsection{DEMs Co-Registration and Topographic Change Detection}

Topographic change detection (TCD) using multi-temporal DEMs was performed by differencing two DEMs of the same area that were derived from data that were taken at different times. This calculation is often affected by errors depending on the presence of a mismatching between two DEMs of the same area, which leads to artefact $\Delta h$ [30]. This error can be detected and reduced by the measurement and minimization of the DEM differences in areas where the two DEMs are supposed to be equal, i.e., those areas that are not reasonably affected by relevant natural changes.

In this work, DEM to DEM coregistration was based on the minimization of the root mean square (RMS) error between one DEM to the other by iteratively varying the three angles of rotation, the translation, and the magnification or reduction factor of one DEM $[39,67,68]$ by using a custom-made algorithm based on the MINUIT minimization library [69]. MINUIT is a tool that can be used to find the minimum value of multiparameter functions and that can be freely downloaded (http: //www.cern.ch/minuit). Coregistration was performed by following the key steps listed below:

1. Preliminary DEMs comparison: Two DEMs were compared, and their differences were visualized in map in order to detect the areas that were affected by topographic changes due to volcanic activity and/or natural phenomena as well as the distribution of errors outside the areas affected by real changes.

2. Detection of target areas and initial RMS displacement calculation: A given number of areas without relevant natural changes around the region of interest, in this case the Sciara del Fuoco scar, were selected for DEMs coregistration and the initial RMS displacement $\left(\sigma_{\Delta Z}^{I N I T I A L}\right)$ between the two DEMs calculated for these areas.

3. Calculation of the minimization parameters: The minimization algorithm based on MINUIT was launched and the minimization parameters, and the final RMS displacement $\left(\sigma_{\Delta Z}^{F I N A L}\right)$ was calculated for the target areas.

4. DEMs coregistration: Minimization parameters were used for coregistering one DEM (slave) on the DEM previously chosen as a reference (master).

5. Selection of independent areas and calculation of RMS displacement error $\left(\sigma_{\Delta Z}\right)$ : Since the areas used for calculating $\sigma_{\Delta Z}^{F I N A L}$ were targeted by the minimization process, $\sigma_{\Delta Z}^{F I N A L}$ could not be used for the error calculations of thicknesses and volumes. Independent areas, not affected by natural changes and that were as close as possible to the region of interest, were used to check the residual mismatching between the two DEMs. Note that in this case, the resulting RMS displacement error was the RMS residuals (in elevation) between one DEM and another arbitrary one chosen as a reference, rather than a true absolute error [68].

The differences between two successive properly coregistered DEMs were used to detect and outline the extent of the areas that were affected by topographic changes (Figure 4) and to calculate the volume and thickness variation inside them (Table 6). Moreover, the perimeters of the observed changes were double checked by using the orthorectified (airborne and PLÉIADES-1) images. The areas where the volumes gained and lost by the SdF were calculated, and the selected profiles are shown in Figures 4 and 5. 

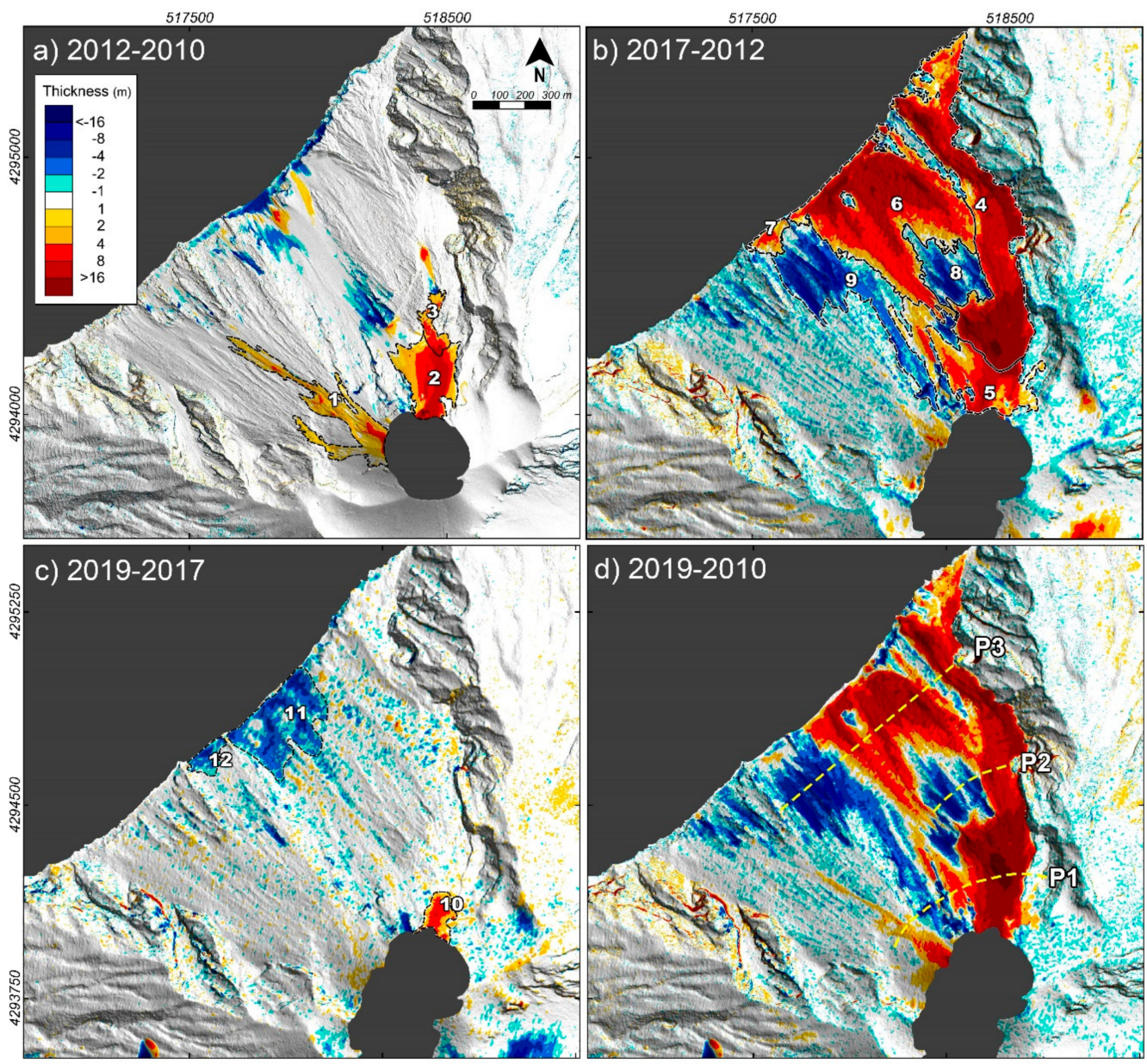

Figure 4. Sciara del Fuoco topographic change detections. (a) May 2012 Light Detection and Ranging (LiDAR) vs. July 2010 LiDAR digital elevation models (DEMs) comparison. (b) May 2012 LiDAR vs. May 2017 PLÉIADES DEMs comparison. (c) September 2019 PLÉIADES vs. May 2017 PLÉIADES DEMs comparison. Dashed lines outline the areas where the volume gain and loss were calculated. (d) September 2018 PLÉIADES vs. July 2010 LiDAR comparison throughout the investigated time interval. P1, P2 and P3 refer to the profile of Figure 5.

Table 6. Topographic change detection results.

\begin{tabular}{|c|c|c|c|c|c|c|}
\hline Time Interval & Sector & Description & $\begin{array}{c}\text { Area } \\
\left(\times 10^{3} \mathrm{~m}^{2}\right)\end{array}$ & $\begin{array}{l}\text { Volume } \\
\left(\times 10^{6} \mathrm{~m}^{3}\right)\end{array}$ & $\begin{array}{l}\text { Mean Thickness } \\
\text { (m) }\end{array}$ & $\sigma_{\Delta Z}(\mathrm{~m})$ \\
\hline \multirow{3}{*}{$\begin{array}{c}\text { July 2010-May } \\
2012\end{array}$} & 1 & December 2010 overflow & 63.817 & $0.118 \pm 0.022$ & 1.850 & 0.350 \\
\hline & 2 & NEC debris talus & 52.927 & $0.289 \pm 0.019$ & 5.465 & 0.350 \\
\hline & 3 & August 2011 overflow & 14.183 & $0.055 \pm 0.005$ & 3.870 & 0.350 \\
\hline \multirow{6}{*}{$\begin{array}{c}\text { May 2012-May } \\
2017\end{array}$} & 4 & 2014 lava flow field & 225.399 & $2.697 \pm 0.190$ & 11.964 & 0.845 \\
\hline & 5 & NEC debris talus & 70.189 & $0.396 \pm 0.059$ & 5.636 & 0.845 \\
\hline & 6 & Volcanoclastic wedge & 242.682 & $1.747 \pm 0.205$ & 7.199 & 0.845 \\
\hline & 7 & Deposition & 12.064 & $0.031 \pm 0.010$ & 2.652 & 0.845 \\
\hline & 8 & Erosion & 52.017 & $-0.153 \pm 0.044$ & -2.948 & 0.845 \\
\hline & 9 & Erosion & 122.655 & $-0.425 \pm 0.104$ & -3.469 & 0.845 \\
\hline \multirow{3}{*}{$\begin{array}{c}\text { June 2019-May } \\
2017\end{array}$} & 10 & NEC debris talus & 15.639 & $0.061 \pm 0.008$ & 3.900 & 0.528 \\
\hline & 11 & Erosion & 84.739 & $-0.214 \pm 0.045$ & -2.524 & 0.528 \\
\hline & 12 & Erosion & 11.962 & $-0.027 \pm 0.006$ & -2.251 & 0.528 \\
\hline
\end{tabular}



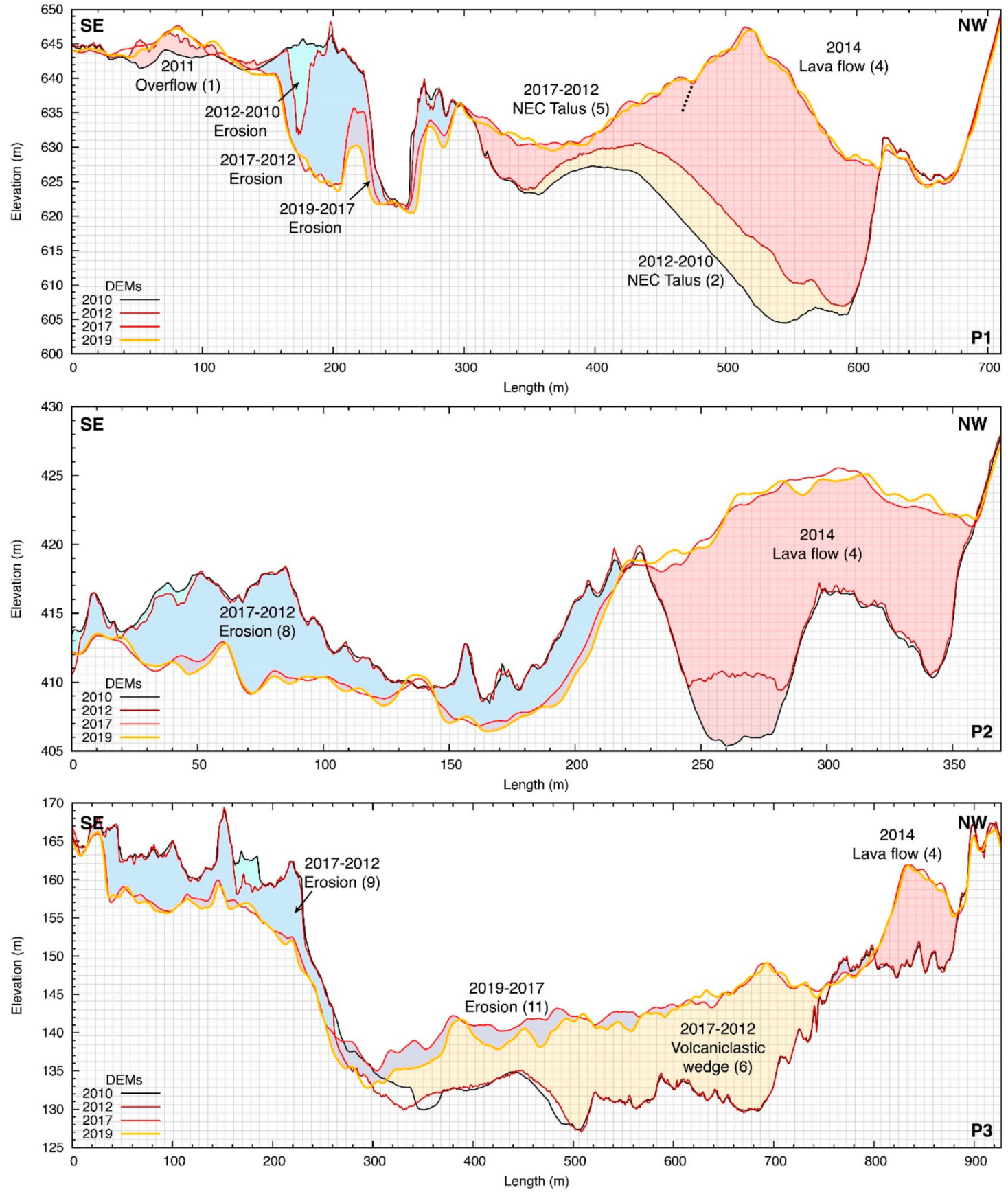

Figure 5. Profiles across the upper (P1), middle (P2) and lower section (P3) of the SdF. The locations of the profiles are represented in Figure $4 \mathrm{~d}$. Labels describe the observed phenomena, and the sectors shown in Figure 4 are reported in brackets. Erosion is illustrated in cold tones, and deposition is illustrated in warm tones. The most recent surface, i.e., the 2019 DEM, is marked by a squared pattern.

The volume $(V)$ emplaced or lost between two acquisitions was calculated from the DEM difference according to the equation: $V=\sum_{i} \Delta x^{2} \Delta z_{i}$ [30], where $x$ is the grid step and $z_{\mathrm{i}}$ is the height variation within grid cell $i$. These values were then summed up for all the cells in the selected areas in which the volume changes were calculated. An upper bound on the error for the volume estimate was given by assigning to each pixel the maximum possible error, i.e., $E r r_{V, \text { high }}=A \sigma_{\Delta Z}$, where $A$ is the investigated area. Thus, the errors provided here are reasonably overestimated [30]. 


\section{Results}

\subsection{DEMs Comparison}

A preliminary comparison between 2010 and 2012 LiDAR DEMs had $\sigma_{\triangle Z}^{I N I T I A L}=0.46 \mathrm{~m}$, which was considered low enough to not require any further correction between the two LiDAR DEMs. In this case, even if no correction was performed, $\sigma_{\Delta Z}$ was lower than $\sigma_{\Delta Z}^{I N I T I A L}$, as it had a value of $0.35 \mathrm{~m}$ (Table 6). The 2012 and 2010 LiDAR DEMs were used as reference data for coregistering the 2017 and 2019 PLÉIADES DEMs, respectively. The 2012-2017 coregistration provided the following values: $\sigma_{\Delta Z}^{\text {INITIAL }}=2.80 \mathrm{~m}, \sigma_{\Delta Z}^{\text {FINAL }}=0.60 \mathrm{~m}$, and $\sigma_{\Delta Z}=0.85 \mathrm{~m}$ (Table 6). The 2012-2017 LiDAR vs. PLÉIADES coregistration was already performed by using a similar method in [41], which provided some slightly different values than this work, i.e., $\sigma_{\Delta Z}^{I N I T I A L}=3.37 \mathrm{~m}, \sigma_{\Delta Z}^{\text {FINAL }}=1.27 \mathrm{~m}$. This difference was due to the different areas that were selected for calculating RMS displacement that included almost the entire island with the exclusion of the SdF. In [41], $\sigma_{\Delta Z}^{F I N A L}$ was used as $\sigma_{\Delta Z}$. The 2010-2019 coregistration provided the following values: $\sigma_{\Delta Z}^{I N I T I A L}=3.54 \mathrm{~m}, \sigma_{\Delta Z}^{\text {FINAL }}=0.61 \mathrm{~m}, \sigma_{\Delta Z}=0.75 \mathrm{~m}$ (Table 6). The 2019-2017 comparison was calculated by comparing the PLÉIADES DEMs before and after their coregistration with LiDAR DEMs. The following RMS displacement areas were calculated: $\sigma_{\Delta Z}^{\text {INITIAL }}=1.06 \mathrm{~m}, \sigma_{\Delta Z}^{\text {FINAL }}=0.46 \mathrm{~m}, \sigma_{\Delta Z}=0.53 \mathrm{~m}$.

Though both PLÉIADES tri-stereo and LiDAR DEMs had $1 \mathrm{~m}$ of spatial resolution, the difference in accuracy can be easily perceived visually. Figure 6a shows a comparison between the hillshading derived from both DEMs of an SdF sector. Due its slope and the type of deposits, this area is not easy to be correctly sensed [70]. The LiDAR modelled the surface without any macroscopic artefacts, allowing for the detection of the complex system of small valleys and ridges inside it. On the other hand, the PLEIADES's DEM showed a diffuse noise, which did not allow for us to distinguish the internal structure of the SdF. This noise was better highlighted by the sky view factor 2 (Figure 6c,d) and the openness down map (Figure 6e,f). Sky view factor 2 (SVF2) is a variant of sky view factor (SVF). The SVF was described by a solid angle $(\Omega)$ open to the sky and is expressed in terms of the total sky view possible from any given pixel, i.e., $\mathrm{SVF}=\Omega / 2 \pi$ [71]. It is a fraction of the sky visible from each pixel and ranges from one to zero. SVF2 also accounts for negative values, allowing for the presence of angles under the horizon, and it can reach a maximum possible value of 2 [71]. SVF2 enhances the perception of the relative height of surface elements, thus helping to detect crests and ridges. The LiDAR DEM clearly showed these structures inside the SdF, thus permitting us to follow their downslope directions (Figure 6c). In the PLÉIADES's DEM, several artefacts cross-cut the SdF, thus masking the smaller structures (Figure 6d). Openness down is a measure of belowground openness [71-73]. It has high values inside valleys, gullies, and craters, effectively resulting in the detection of cracks and fractures [68]. An openness down map derived from LiDAR showed well-defined valley directed downslope (Figure 6e), while the PLÉIADES one highlighted the artefact "cobble" texture inside the SdF (Figure 6f). 

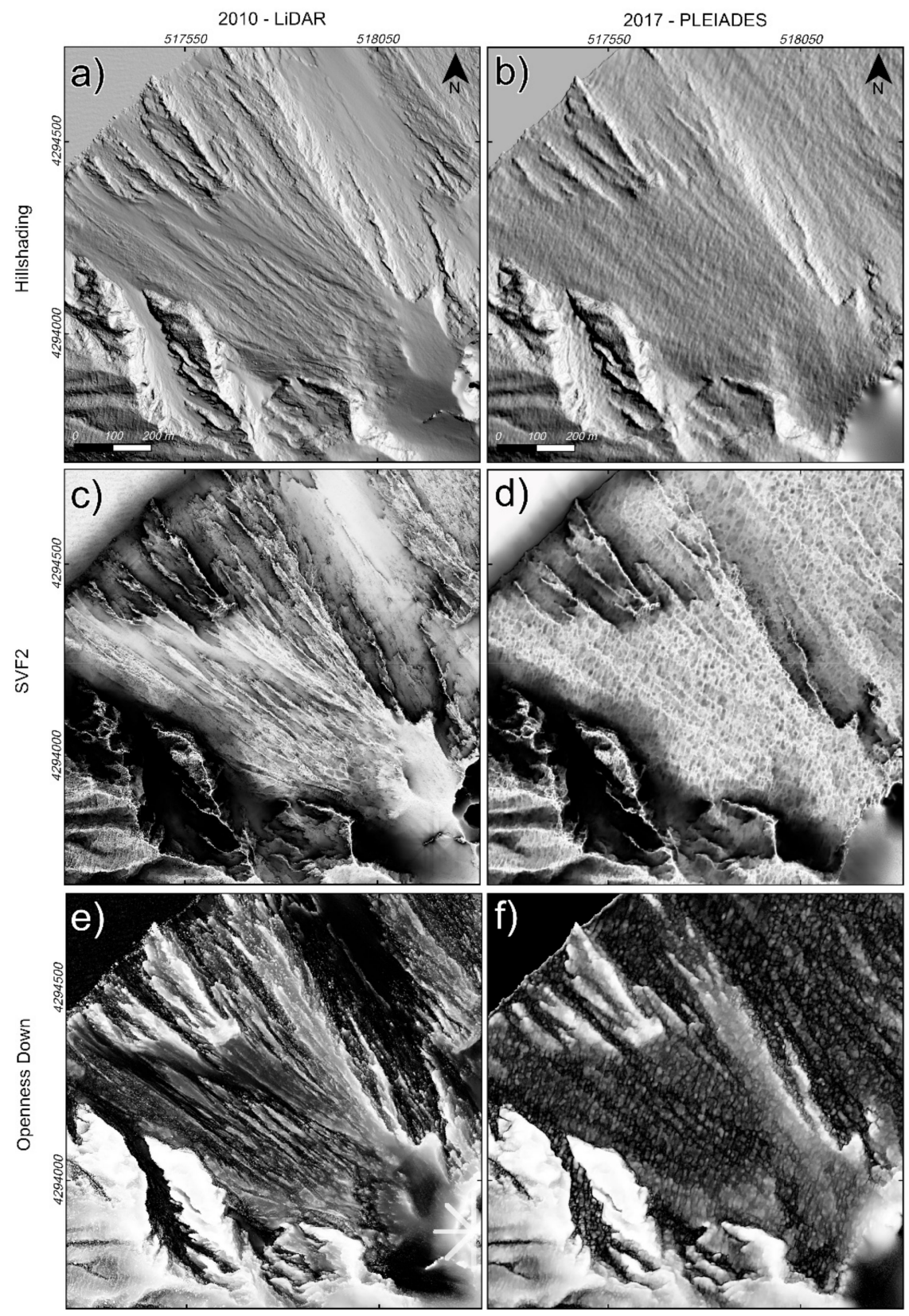

Figure 6. 2010 LiDAR DEM and 2017 PLÉIADES DEM visual comparison of a west SdF sector. (a) Hill-shaded map, (c) sky view factor 2 map, and (e) openness down (crack map) image derived from the LiDAR DEM. (b) Hill-shaded map, (d) sky view factor 2 map, and (f) openness down map derived from the PLÉIADES DEM.

In small areas that were supposed to be flat surfaces, the PLÉIADES and LiDAR DEMs $z$ mean, range, and standard deviation were also compared (see Supplementary Materials), i.e., the football pitch $\left(2357 \mathrm{~m}^{2}\right)$ and the helipad $\left(1435 \mathrm{~m}^{2}\right)$ at the Stromboli village and the helipad at Ginostra $\left(366 \mathrm{~m}^{2}\right)$. At the Stromboli village helipad, the $z$ of the 2010 LiDAR DEMs had mean value of $3.08 \mathrm{~m}$, a standard deviation of $0.11 \mathrm{~m}$, and a range of 2.8-3.5 m. The 2017 coregistered PLÉIADES DEMs had a mean value of 2.70, a standard deviation of 0.16 , and a range of $2.07-3.20 \mathrm{~m}$. At the football pitch, the $z$ of 2010 LiDAR DEMs had a mean value of $30.93 \mathrm{~m}$, a standard deviation of $0.04 \mathrm{~m}$ and a range of 30.81-31.40 m. The 2017 coregistered PLÉIADES DEMs had a mean value of $30.45 \mathrm{~m}$, a standard deviation of $0.18 \mathrm{~m}$, and a range of 30.01-30.94 m. At the Ginostra helipad, the $z$ of 2010 LiDAR DEMs had a mean value of $56.16 \mathrm{~m}$, a standard deviation of $0.04 \mathrm{~m}$, and a range of $56.04-56.25 \mathrm{~m}$. The 2017 
coregistered PLÉIADES DEMs had a mean value of $55.52 \mathrm{~m}$, a standard deviation of $0.15 \mathrm{~m}$, and a range of $55.18-55.93 \mathrm{~m}$.

These data agree with a previous analysis that was carried out in [74,75], whose authors found that the elevation differences between LiDAR and PLÉIADES data in urban areas and farmlands are largely on the order $\pm 1 \mathrm{~m}$.

At the same time, by observing the profiles of Figure 5, it is possible to appreciate the coherence among the PLÉIADES and LiDAR DEMs, where no natural morphological changes were expected (i.e. at the northwestern sectors of each profile). A good agreement between the PLÉIADES and LIDAR data was described by [74,75]. However, the latter also reported the presence of a noise in the PLÉIADES tri-stereo DEMs, suggesting its use only for features greater than $2 \mathrm{~m}$.

\subsection{Morphological Changes}

The integration of the TCD and the analysis based of the optical images were the basis for the definition of the short-term (between July 2010 and June 2019) geomorphological evolution of the SdF steep-slope, which is frequently affected by an accumulation of volcanic material, erosion, and mass-wasting phenomena. Major variations are illustrated in Figures 4 and 5, and volume changes are shown in Table 6.

The period between July 2010 and May 2012 showed changes (Figures 4a and 5) only related to phases of more intense eruptive activity (stronger/frequent explosions and overflows). The lava overflowed from the South-Western Crater (SWC) area on 11-12 December 2011 [44]. It diverged in two branches. The southernmost was $400 \mathrm{~m}$ long and reached $560 \mathrm{~m}$ a.s.l., and the northernmost was longer at $730 \mathrm{~m}$ and reached a minimum elevation of about $207 \mathrm{~m}$ a.s.l. (Figures $4 \mathrm{a}$ and 5, region 1). From the same crater, a small overflow also occurred on 18 August 2011, which emplaced over the 11-12 December overflow [44]. Both overflow emplaced a volume of $0.118 \pm 0.022 \times 10^{6} \mathrm{~m}^{3}$ of lava outside the crater terrace, with a mean thickness of $1.850 \mathrm{~m}$. Overflow also occurred on 1-2 August 2011 from the NEC (Figure 4a, region 3) [54]. The lava run over a pre-existing debris talus accumulated below the NEC (Figure 4a, region 2 and Figure 5, P1). The lava front reached a minimum elevation of $530 \mathrm{~m}$ after having flowed a distance of $470 \mathrm{~m}$. The deposits forming the debris talus later covered the feeding channel of the 1-2 August overflow, which was no longer visible at the time of the 2012 LiDAR survey. Though it was not possible to distinguish the debris talus from the lava where they overlapped, their volumes, which must be considered as an approximation of the real values, were provided. Region 2 of Figure 4a, which was most related to the debris talus, had a volume of $0.289 \pm 0.019 \times 10^{6} \mathrm{~m}^{3}$ for a mean thickness of $5.465 \mathrm{~m}$. The terminal part of the lava flow, which included the distal sector of the feeding channel and the dispersed flow (Figure 4a, region 3), had a volume of $0.055 \pm 0.005 \times 10^{6} \mathrm{~m}^{3}$ with a mean thickness of $3.870 \mathrm{~m}$. In profile 1 of Figure 5, it is also possible to observe a small area that was strongly affected by erosion, which caused the loss of a rock wall of about $14 \mathrm{~m}$. This was due to the disaggregation of the March 2002 lava flow to just north of the 2011 overflow, which was affected by headward erosion.

During the period between May 2012 and May 2017, large topographic changes occurred. The largest variations were related to the emplacement of the 2014 lava flow field in the NE part of the SdF (Figure 4b, region 4). The 2014 lava flow volume that was calculated here was $2.697 \pm 0.190 \times 10^{6}$ $\mathrm{m}^{3}$. This value differs from the volume that was calculated in [41], which was $3.07 \pm 0.37 \times 10^{6} \mathrm{~m}^{3}$, because the NEC talus (sector 5) was not included here. In any case, part of this talus was included in the volume calculation because it was not possible to distinguish between the talus and the proximal sector of the lava (Figure 5, P2). The lava average thickness was $11.964 \mathrm{~m}$. In the median portion of the SdF, the lava filled pre-existing depressions (Figure 5, P2), substantially changing the morphology of the SdF. Here, the flow emplaced up to $10 \mathrm{~m}$ of lava (Figure 5, P2). In the distal part of the SdF, the flow had no morphological constraints and emplaced lava up to $13 \mathrm{~m}$ along profile 2 (Figure 5, P2), arriving elsewhere over $20 \mathrm{~m}$. The remaining sector of the NEC talus accumulated material for 0.396 $\pm 0.059 \times 10^{6} \mathrm{~m}^{3}$, probably both before and after the 2014 lava emplacement (Figure 5, P1). In the 
central part of the SdF, from 2012 to 2017, a huge volcanoclastic wedge accumulated (Figure 4b, region 6 and Figure 5, P3) for a total volume of $1.747 \pm 0.205 \times 10^{6} \mathrm{~m}^{3}$, with a medium thickness of $7.2 \mathrm{~m}$, locally reaching 18-19 m (Figure 5, P3). During the same time period, the SdF has been affected by massive erosive phenomena. The older lava has been affected by headward erosion, which is visible in profile 1 of Figure 5, carried on to lose material. Besides this, two large areas have been affected by erosion: one constrained between the 2014 lava and the volcaniclastic wedge (Figure 4b, region 8) and the other south of the volcaniclastic wedge (Figure $4 b$, sector 9). Erosion in region 8 caused the loss of $0.153 \pm 0.044 \times 10^{6} \mathrm{~m}^{3}$ of volcaniclastic material for a mean thickness loss of just below $3 \mathrm{~m}$. Locally, the erosion had high impact, arriving at $10 \mathrm{~m}$ of thickness lost (Figure 5, P2). The erosion rate in this sector was about $2.5 \times 10^{3} \mathrm{~m}^{3} /$ month. Region 9 was wider than region 8 ; it lost $0.425 \pm 0.104 \times 10^{6} \mathrm{~m}^{3}$ of material for a mean thickness loss of just below $3.5 \mathrm{~m}$, arriving locally even just over $10 \mathrm{~m}$. The erosion rate in this sector was about $7.1 \times 10^{3} \mathrm{~m}^{3} /$ month. The material eroded in region 9 partially accumulated downslope for a volume of $0.031 \pm 0.010 \times 10^{6} \mathrm{~m}^{3}$ (Figure $4 \mathrm{~b}$, sector 7).

Between 2017 and 2019, Strombolian activity kept increasing the volume of the NEC talus of $0.061 \pm 0.008 \times 10^{6} \mathrm{~m}^{3}$ for a mean increase in thickness of $3.9 \mathrm{~m}$ (Figure $4 \mathrm{c}$, region 10). Besides this, two eroded areas in the lower SdF were detected (Figure 4c, sector 11 and 12) that corresponded to sectors 6 and 7 of Figure 4b, respectively, where deposits had accumulated between 2012 and 2017 (Figure 5, P3). In particular, the volume eroded in sector 11 was $0.214 \pm 0.045 \times 10^{6} \mathrm{~m}^{3}$ for a mean lost in thickness of $2.5 \mathrm{~m}$, locally arriving up to $4 \mathrm{~m}$ (Figure 5, P3). Region 12 lost $0.027 \pm 0.006 \times 10^{6} \mathrm{~m}^{3}$ of material and a $2.5 \mathrm{~m}$ of thickness. The mean erosion rates were $8.2 \times 10^{3} \mathrm{~m}^{3} / \mathrm{month}$ for sector 11 and $1.0 \times 10^{3} \mathrm{~m}^{3} /$ month for sector 12 .

The phenomena affecting the SdF obviously influenced its coastline where the sea also plays a role. Between 2010 and 2012, coastline mainly regression occurred in the northern SdF, while the southern sector seemed not unaffected by erosion. Considering that during this period only minor changes occurred in the SdF, this erosion could be imputable to the sea action. In the most affected area, the shoreline retreated by 15-17 m for a retreat rate of $0.6 \mathrm{~m} / \mathrm{month}$. Between 2012 and 2017, the shoreline slightly retreated in the southern SdF and strongly advanced in the northern SdF due to action of the deposition of the volcaniclastic wedge (Figure $4 b$, region 6 ). In the eroded sector, the shoreline retreated of about 10 on average, and it advanced up to $30 \mathrm{~m}$ in the deposition region. Additionally, in the extremely north sector of the SdF, the coastline advanced due to the emplacement of 2014 lava (Figure 4b, region 4). Between 2017 and 2019, shoreline retreating was visible in the northern SdF, arriving up to $12-14 \mathrm{~m}$ for a retreat rate of $0.5 \mathrm{~m} / \mathrm{month}$.

\section{Discussion}

The 2010-2019 volcanic activity fluctuated in the intensity and eruptive style from mild-explosive (Strombolian) to effusive [2,41,44,53,55-59]. This led to an oscillating production of volcaniclastic material and the emplacement of a lava flow filed and several lava overflows [23,41]. During periods characterized by a low intensity/frequency of Strombolian activity, the production of materials ejected from the crater terrace towards the SdF was generally low, and erosion was the prevailing process, mainly affecting the central sector of the SdF. After the 2014 flank eruption, the gravitational re-adjustment of the lava breccia sometimes produced rockfalls [23,41].

The data presented here allow for the reconstruction of the 2010-2019 geomorphological evolution of the SdF slope (Figure 7; Table 7). The main source area of volcanic material is the crater area, where the deposition of scoria bombs-to-ash deposits raised the crater terrace floor, constructing scoria cones within it, and accumulating spatter agglutinates, and forming hornitos. The (volcaniclastic/lava) material temporarily stored in the proximal and medial areas was usually remobilized due to gravity (in high-angle zones), such as erosion or landslides. In medial areas, characterized by the presence of volcaniclastic deposits (i.e., the central part of the SdF), the flowing of lavas or grain flows could have produced erosion and remobilization of material. The distal area was also a temporary storage area where the phenomena of accumulation from higher elevation counteracted the sea erosion. 
With the addition of the results of previous works on the submarine part $[47,48,60,75-77]$, it was possible to identify other main temporary storage areas (the near-coast volcaniclastic apron identified by $[60,76,77])$ up to the most distal zones, which have been reached sporadically by the most energetic phenomena $[47,48]$.

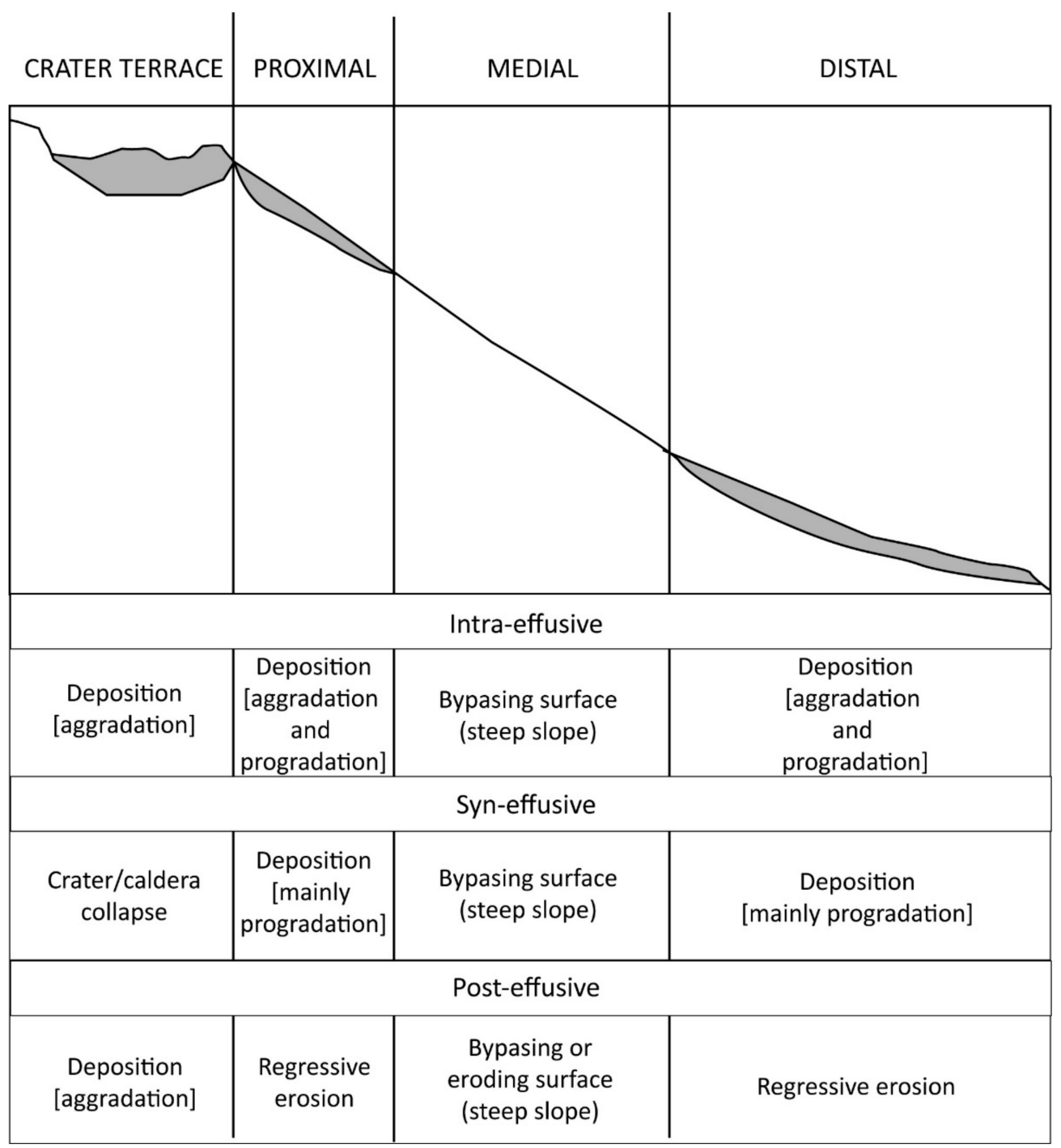

Figure 7. Deposits geometry during Sciara del Fuoco subaerial slope evolution (following [76]).

Table 7. Landforms, deposits and processes occurring in the subaerial part of the Sciara del Fuoco.

\begin{tabular}{|c|c|c|c|c|}
\hline & Crater Terrace & Proximal & Medial & Distal \\
\hline $\begin{array}{l}\text { Landform } \\
\text { (erosion and } \\
\text { mass-wasting) }\end{array}$ & $\begin{array}{ll}\text { - } & \text { Landslide scar } \\
\text { - } & \text { Crater/caldera collapse }\end{array}$ & Landslide scar & $\begin{array}{ll}- & \text { Rills and gullies } \\
- & \text { Large landslide scar } \\
\text { - } & \text { Bypassing surface }\end{array}$ & $\begin{array}{ll}- & \text { Rills and gullies } \\
- & \text { Large landslide scar } \\
- & \text { Small cliffs }\end{array}$ \\
\hline $\begin{array}{c}\text { Landform } \\
\text { (sedimentation) }\end{array}$ & $\begin{array}{ll}- & \text { Scoria cones } \\
\text { - } & \text { Hornitos }\end{array}$ & $\begin{array}{ll}- & \text { Debris talus } \\
\text { - } & \text { Lava shields talus }\end{array}$ & $\begin{array}{ll}\text { - } & \text { Volcaniclastic lobes } \\
\text { - } & \text { Lava lobes, lava fields }\end{array}$ & $\begin{array}{ll}\text { - } & \text { Volcaniclastic lobes } \\
\text { - } & \text { Lava lobes, lava fields } \\
\text { - } & \text { Lava deltas }\end{array}$ \\
\hline
\end{tabular}


Table 7. Cont.

\begin{tabular}{|c|c|c|c|c|}
\hline & Crater Terrace & Proximal & Medial & Distal \\
\hline Deposits & $\begin{array}{ll}\text { - } & \text { Bombs and } \\
& \text { lapilli deposit } \\
\text { - } & \text { Spatter agglomerates }\end{array}$ & $\begin{array}{ll}\text { - } & \text { Bombs and } \\
\text { lapilli deposit } \\
\text { - } & \text { Volcanoclastic } \\
\text { debris lobes } \\
\text { - } \quad \text { Lava lobes with } \\
\text { variable amount of } \\
\text { external breccia }\end{array}$ & $\begin{array}{ll}\text { - } & \text { Volcanoclastic } \\
\text { debris lobes } \\
\text { - } & \text { Lava lobes with } \\
\text { variable amount of } \\
\text { external breccia } \\
\text { - Lava field with } \\
\text { variable amount of } \\
\text { external breccia }\end{array}$ & $\begin{array}{ll}\text { - } & \text { Volcanoclastic } \\
\text { debris lobes } \\
\text { - } & \text { Volcanoclastic } \\
\text { debris aprons } \\
\text { - } \quad \text { Lava lobes with variable } \\
\text { amount of } \\
\text { external breccia } \\
\text { - } \quad \text { Lava field with variable } \\
\text { amount of } \\
\text { external breccia }\end{array}$ \\
\hline $\begin{array}{l}\text { Processes } \\
\text { (depletion) }\end{array}$ & Rockfalls & $\begin{array}{ll}- & \text { Grain flows } \\
- & \text { Debris } \\
& \text { talus collapse } \\
\text { - } & \text { Rockfalls }\end{array}$ & $\begin{array}{ll}- & \text { Grain flows } \\
- & \text { Rockfalls } \\
- & \text { Rock/debris } \\
& \text { avalanches detachment } \\
- & \text { Creep } \\
- & \text { Mountain } \\
& \text { slope deformation }\end{array}$ & $\begin{array}{ll}- & \text { Grain flows } \\
- & \text { Rockfalls } \\
- & \text { Rock/debris } \\
\text { avalanches detachment } \\
-\quad & \text { Creep } \\
- & \text { Mountain } \\
\text { slope deformation } \\
-\quad & \text { Volcanoclastic } \\
- & \text { deposit erosion } \\
- & \text { Coastal erosion } \\
\text { Volcanoclastic cliffs } \\
\text { subject to undercutting } \\
\text { and collapse }\end{array}$ \\
\hline $\begin{array}{c}\text { Processes } \\
\text { (accumulation) }\end{array}$ & $\begin{array}{ll}- & \text { Scoria fallout } \\
- & \text { Spatter agglutination }\end{array}$ & $\begin{array}{ll}- & \text { Scoria fallout } \\
- & \text { Lava overflows } \\
- & \text { Grain flows } \\
- & \text { Lava field }\end{array}$ & $\begin{array}{ll}- & \text { Lava overflows } \\
- & \text { Lava field } \\
- & \text { Grain flows }\end{array}$ & $\begin{array}{ll}- & \text { Lava overflows } \\
- & \text { Lava field } \\
- & \text { Lava delta } \\
- & \text { Grain flows } \\
- & \text { Beach formation }\end{array}$ \\
\hline
\end{tabular}

The combination of this work with the results of [23] provides an evolutionary framework, at least for the period after the 2007 eruption. This work shows that the emplacement of the lava field of 2014 was preceded and accompanied by the accumulation of a volcanoclastic wedge from the mid-slope to the coastline (and also below) $[60,78,79]$. In this case, the positive anomalies detected by the TCD must have been produced by the lava flow field and also by the volcanoclastic materials that were deposited during periods of high explosive activity. These results are partly in contradiction with the statement made in [32]. The authors of that article suggested that the accumulation of material on the SdF depends only on the effusive phases, and, therefore, the positive anomalies in the TCDs should be ascribed only to the emplacement of lava flows. The quantification of this volcanoclastic wedge is relevant, as is the submarine volcanoclastic apron, because it was composed of the same material that was involved in the 30 December, 2002 tsunamigenic landslide [77] in addition to being located in the same area.

\section{Conclusions}

In this work, the geomorphological responses to the volcanic activity at the Stromboli steep-slope volcano were identified by means of DEM comparisons. The results were strengthened by the analysis of medium and high-resolution satellite optical images. Multi-temporal lithology and landform variations depended on the shift in spatial and temporal distribution of processes. Stromboli, as many other frequently active volcanos, is characterized by periods of low volcaniclastic productivity (no or low-level volcanic activity) when erosion prevails, and this erosion if mainly concentrated on the loose, older volcaniclastic deposits. On the other side, the increase in the explosive activity produces more volcaniclastic material with a consequent increase in sedimentation along the slope. The main source area of volcanic material is the crater area, where volcanic activity is used to accumulating spatter agglutinates, forming hornitos. Lava accumulation can occur in different positions, depending on the location of the eruptive vent and the effusive rate.

This work shows that the differences between DEMs, if not acquired at high temporal frequency, should be accompanied by other observations (such as those based on optical images) in order not 
to incur the error of attributing topographical variations to a single event/a single lithology. In the case of Stromboli, the topographic changes between May 2012 and May 2017 are not due only to the emplacement of the lava field 2014 but also due to the accumulation of the volcanoclastic wedge. The presence of material with different technical characteristics is fundamental in a volcano flank that is prone to landslide, since it allows for the identification of more unstable volumes.

The comparison between the accuracy levels of PLÉIADES and LiDAR DEMs that was performed here should be considered preliminary and not exhaustive. Further analysis must involve the source data, the used modelling methods, and data that were acquired with various methods at different times. Having stated this, a first indication on the differences between two largely used methods for modelling topography in volcanic areas is provided here. This analysis can be used by the volcanological community and the civil protection authorities in case of a cost-benefit analysis for planning the best method for updating the topography and quantifying the morphological changes of an active, steep-slope volcano.

This study demonstrates how remote sensing data is useful for monitoring eruptive and geomorphological phenomena in active volcanic areas. This approach can be applied to other volcanic areas that are characterized by similar phenomena, but at the same time it can be generalized and applied in other geological contexts that are characterized by steep slopes.

Supplementary Materials: The following are available online at http://www.mdpi.com/2072-4292/12/3/438/s1, Figure S1: visual estimation of accuracy estimation between LiDAR and PLÉIADES tri-stereo DEMs, Table S1: PLÉIADES tri-stereo DEMs accuracu estimation.

Author Contributions: Conceptualization: F.D.T., A.F., M.F., T.N.; Data analysis: F.D.T., A.F., M.F., T.N.; Writing-Original Draft Preparation: F.D.T., A.F., M.F.; Writing-Review \& Editing: T.N., N.C. All authors have read and agreed to the published version of the manuscript.

Funding: This work has been financially supported by the "Presidenza del Consiglio dei Ministri - Dipartimento della Protezione Civile" (Presidency of the Council of Ministers - Department of Civil Protection) (Scientific Responsibility: NC); this publication, however, does not reflect the position and the official policies of the Department. This work has been financially supported by "Volcano Sentinel—extension" project (Call: "Settore ricerca scientifica e innovazione tecnologica"; founded by: Ente Cassa di Risparmio di Firenze. Scientific Responsibility: FeDiT).

Acknowledgments: This work was financially supported by the "Presidenza del Consiglio dei Ministri Dipartimento della Protezione Civile" (Presidency of the Council of Ministers - Department of Civil Protection); this publication, however, does not reflect the position and official policies of the Department. This work was financially supported by the "Volcano Sentinel - extension" project (Call: "Settore ricerca scientifica e innovazione tecnologica"; funded by: Ente Cassa di Risparmio di Firenze. Scientific Responsibility: Federico Di Traglia). The authors are grateful to Tullio Ricci (INGV-Roma) for discussions on the morphological evolution of Stromboli volcano.

Conflicts of Interest: The authors declare no conflict of interest.

\section{References}

1. Thouret, J.C. Volcanic geomorphology-An overview. Earth-Sci. Rev. 1999, 47, 95-131. [CrossRef]

2. Schaefer, L.N.; Di Traglia, F.; Chaussard, E.; Lu, Z.; Nolesini, T.; Casagli, N. Monitoring volcano slope instability with Synthetic Aperture Radar: A review and new data from Pacaya (Guatemala) and Stromboli (Italy) volcanoes. Earth-Sci. Rev. 2019, 192, 236-257. [CrossRef]

3. Wadge, G.; Francis, P.W.; Ramirez, C.F. The Socompa collapse and avalanche event. J. Volcanol. Geotherm. Res. 1995, 66, 309-336. [CrossRef]

4. Chorowicz, J.; Deffontaines, B.; Huaman-Rodrigo, D.; Guillande, R.; Leguern, F.; Thouret, J.C. SPOT satellite monitoring of the eruption of Nevado Sabancaya volcano (Southern Peru). Remote Sens. Environ. 1992, 42, 43-49. [CrossRef]

5. Chorowicz, J.; Lopez, E.; Garcia, F.; Parrot, J.F.; Rudant, J.P.; Vinluan, R. Keys to analyze active lahars from Pinatubo on SAR ERS imagery. Remote Sens. Environ. 1997, 62, 20-29. [CrossRef]

6. Kerle, N.; Froger, J.L.; Oppenheimer, C.; Vries, B.V.W.D. Remote sensing of the 1998 mudflow at Casita volcano, Nicaragua. Int. J. Remote Sens. 2003, 24, 4791-4816. [CrossRef] 
7. Torres, R.; Mouginis-Mark, P.; Self, S.; Garbeil, H.; Kallianpur, K.; Quiambao, R. Monitoring the evolution of the Pasig-Potrero alluvial fan, Pinatubo Volcano, using a decade of remote sensing data. J. Volcanol. Geotherm. Res. 2004, 138, 371-392. [CrossRef]

8. Ernst, G.G.J.; Kervyn, M.; Teeuw, R.M. Advances in the remote sensing of volcanic activity and hazards, with special consideration to applications in developing countries. Int. J. Remote Sens. 2008, 29, 6687-6723. [CrossRef]

9. Canisius, F.; Honda, K.; Tokunaga, M. Updating geomorphic features of watersheds and their boundaries in hazardous areas using satellite synthetic aperture radar. Int. J. Remote Sens. 2009, 30, 5919-5933. [CrossRef]

10. Thouret, J.C.; Gupta, A.; Lube, G.; Liew, S.C.; Cronin, S.J. The 2006 pyroclastic deposits of Merapi Volcano, Java, Indonesia: High-spatial resolution IKONOS images and complementary ground based observations. Remote Sens. Environ. 2010, 114, 1949-1967. [CrossRef]

11. Wadge, G.; Cole, P.; Stinton, A.; Komorowski, J.C.; Stewart, R.; Toombs, A.C.; Legendre, Y. Rapid topographic change measured by high-resolution satellite radar at Soufriere Hills Volcano, Montserrat, 2008-2010. J. Volcanol. Geotherm. Res. 2011, 199, 142-152. [CrossRef]

12. Dietterich, H.R.; Poland, M.P.; Schmidt, D.A.; Cashman, K.V.; Sherrod, D.R.; Espinosa, A.T. Tracking lava flow emplacement on the east rift zone of Kîlauea, Hawai 'i, with synthetic aperture radar coherence. Geochem. Geophys. Geosyst. 2012, 13, Q05001. [CrossRef]

13. Ebmeier, S.K.; Biggs, J.; Mather, T.A.; Elliott, J.R.; Wadge, G.; Amelung, F. Measuring large topographic change with InSAR: Lava thicknesses, extrusion rate and subsidence rate at Santiaguito volcano, Guatemala. Earth Planet. Sci. Lett. 2012, 335, 216-225. [CrossRef]

14. Ebmeier, S.K.; Biggs, J.; Muller, C.; Avard, G. Thin-skinned mass-wasting responsible for widespread deformation at Arenal volcano. Front. Earth Sci. 2014, 2, 35. [CrossRef]

15. Kassouk, Z.; Thouret, J.C.; Gupta, A.; Solikhin, A.; Liew, S.C. Object-oriented classification of a high-spatial resolution SPOT5 image for mapping geology and landforms of active volcanoes: Semeru case study, Indonesia. Geomorphology 2014, 221, 18-33. [CrossRef]

16. Solikhin, A.; Pinel, V.; Vandemeulebrouck, J.; Thouret, J.C.; Hendrasto, M. Mapping the 2010 Merapi pyroclastic deposits using dual-polarization Synthetic Aperture Radar (SAR) data. Remote Sens. Environ. 2015, 158, 180-192. [CrossRef]

17. Solikhin, A.; Thouret, J.C.; Liew, S.C.; Gupta, A.; Sayudi, D.S.; Oehler, J.F.; Kassouk, Z. High-spatial-resolution imagery helps map deposits of the large (VEI 4) 2010 Merapi Volcano eruption and their impact. Bull. Volcanol. 2015, 77, 20. [CrossRef]

18. Thouret, J.C.; Kassouk, Z.; Gupta, A.; Liew, S.C.; Solikhin, A. Tracing the evolution of 2010 Merapi volcanic deposits (Indonesia) based on object-oriented classification and analysis of multi-temporal, very high resolution images. Remote Sens. Environ. 2015, 170, 350-371. [CrossRef]

19. Arnold, D.W.D.; Biggs, J.; Wadge, G.; Ebmeier, S.K.; Odbert, H.M.; Poland, M.P. Dome growth, collapse, and valley fill at Soufrière Hills Volcano, Montserrat, from 1995 to 2013: Contributions from satellite radar measurements of topographic change. Geosphere 2016, 12, 1300-1315. [CrossRef]

20. Arnold, D.W.D.; Biggs, J.; Anderson, K.; Vallejo Vargas, S.; Wadge, G.; Ebmeier, S.K.; Naranjo, M.F.; Mothes, P. Decaying Lava Extrusion Rate at El Reventador Volcano, Ecuador, Measured Using High-Resolution Satellite Radar. J. Geophys. Res.: Solid Earth 2017, 122, 9966-9988. [CrossRef]

21. Chaussard, E. A low-cost method applicable worldwide for remotely mapping lava dome growth. J. Volcanol. Geotherm. Res. 2017, 341, 33-41. [CrossRef]

22. Arnold, D.W.D.; Biggs, J.; Wadge, G.; Mothes, P. Using satellite radar amplitude imaging for monitoring syn-eruptive changes in surface morphology at an ice-capped stratovolcano. Remote Sens. Environ. 2018, 209, 480-488. [CrossRef]

23. Di Traglia, F.; Nolesini, T.; Ciampalini, A.; Solari, L.; Frodella, W.; Bellotti, F.; Fumagalli, A.; De Rosa, G.; Casagli, N. Tracking morphological changes and slope instability using spaceborne and ground-based SAR data. Geomorphology 2018, 300, 95-112. [CrossRef]

24. Coltelli, M.; Proietti, C.; Branca, S.; Marsella, M.; Andronico, D.; Lodato, L. Analysis of the 2001 lava flow eruption of Mt. Etna from three-dimensional mapping. J. Geophys. Res.: Earth Surf. 2007, 112, F02029. [CrossRef] 
25. Baldi, P.; Fabris, M.; Marsella, M.; Monticelli, R. Monitoring the morphological evolution of the Sciara del Fuoco during the 2002-2003 Stromboli eruption using multi-temporal photogrammetry. Isprs J. Photogramm. Remote Sens. 2005, 59, 199-211. [CrossRef]

26. Neri, M.; Lanzafame, G. Structural features of the 2007 Stromboli eruption. J. Volcanol. Geotherm. Res. 2009, 182, 137-144. [CrossRef]

27. Baldi, P.; Coltelli, M.; Fabris, M.; Marsella, M.; Tommasi, P. High precision photogrammetry for monitoring the evolution of the NW flank of Stromboli volcano during and after the 2002-2003 eruption. Bull. Volcanol. 2008, 70, 703-715. [CrossRef]

28. Marsella, M.; Proietti, C.; Sonnessa, A.; Coltelli, M.; Tommasi, P.; Bernardo, E. The evolution of the Sciara del Fuoco subaerial slope during the 2007 Stromboli eruption: Relation between deformation processes and effusive activity. J. Volcanol. Geotherm. Res. 2009, 182, 201-213. [CrossRef]

29. Favalli, M.; Karátson, D.; Mazzarini, F.; Pareschi, M.T.; Boschi, E. Morphometry of scoria cones located on a volcano flank: A case study from Mt. Etna (Italy), based on high-resolution LiDAR data. J. Volcanol. Geotherm. Res. 2009, 186, 320-330. [CrossRef]

30. Favalli, M.; Fornaciai, A.; Mazzarini, F.; Harris, A.; Neri, M.; Behncke, B.; Pareschi, M.T.; Tarquini, S.; Boschi, E. Evolution of an active lava flow field using a multitemporal LIDAR acquisition. J. Geophys. Res.: Solid Earth 2010, 115, B11203. [CrossRef]

31. Fornaciai, A.; Behncke, B.; Favalli, M.; Neri, M.; Tarquini, S.; Boschi, E. Detecting short-term evolution of Etnean scoria cones: A LIDAR-based approach. Bull. Volcanol. 2010, 72, 1209-1222. [CrossRef]

32. Marsella, M.; Baldi, P.; Coltelli, M.; Fabris, M. The morphological evolution of the Sciara del Fuoco since 1868: Reconstructing the effusive activity at Stromboli volcano. Bull. Volcanol. 2012, 74, 231-248. [CrossRef]

33. Behncke, B.; Branca, S.; Corsaro, R.A.; De Beni, E.; Miraglia, L.; Proietti, C. The 2011-2012 summit activity of Mount Etna: Birth, growth and products of the new SE crater. J. Volcanol. Geotherm. Res. 2014, 270, 10-21. [CrossRef]

34. De Beni, E.; Behncke, B.; Branca, S.; Nicolosi, I.; Carluccio, R.; Caracciolo, F.A.; Chiappini, M. The continuing story of Etna's New Southeast Crater (2012-2014): Evolution and volume calculations based on field surveys and aerophotogrammetry. J. Volcanol. Geotherm. Res. 2015, 303, 175-186. [CrossRef]

35. Bagnardi, M.; González, P.J.; Hooper, A. High-resolution digital elevation model from tri-stereo PLÉIADES-1 satellite imagery for lava flow volume estimates at Fogo Volcano. Geophys. Res. Lett. 2016, 43, 6267-6275. [CrossRef]

36. Behncke, B.; Fornaciai, A.; Neri, M.; Favalli, M.; Ganci, G.; Mazzarini, F. Lidar surveys reveal eruptive volumes and rates at Etna, 2007-2010. Geophys. Res. Lett. 2016, 43, 4270-4278. [CrossRef]

37. Roberti, G.; Ward, B.; de Vries, B.V.W.; Friele, P.; Perotti, L.; Clague, J.J.; Giardino, M. Precursory slope distress prior to the 2010 Mount Meager landslide, British Columbia. Landslides 2018, 15, 1-11. [CrossRef]

38. Roberti, G.; Friele, P.; de Vries, B.V.W.; Ward, B.; Clague, J.J.; Perotti, L.; Giardino, M. Rheological evolution of the Mount Meager 2010 debris avalanche, southwestern British Columbia. Geosphere 2017, 13, 369-390. [CrossRef]

39. Richter, N.; Favalli, M.; de Zeeuw-van Dalfsen, E.; Fornaciai, A.; Fernandes, R.M.D.S.; Pérez, N.M.; Levy, J.; Silva Victoria, S.; Walter, T.R. Lava flow hazard at Fogo Volcano, Cabo Verde, before and after the 2014-2015 eruption. Nat. Hazards Earth Syst. Sci. 2016, 16, 1925. [CrossRef]

40. Naranjo, M.F.; Ebmeier, S.K.; Vallejo, S.; Ramón, P.; Mothes, P.; Biggs, J.; Herrera, F. Mapping and measuring lava volumes from 2002 to 2009 at El Reventador Volcano, Ecuador, from field measurements and satellite remote sensing. J. Appl. Volcanol. 2016, 5, 8. [CrossRef]

41. Di Traglia, F.; Calvari, S.; D’Auria, L.; Nolesini, T.; Bonaccorso, A.; Fornaciai, A.; Esposito, A.; Cristaldi, A.; Favalli, M.; Casagli, N. The 2014 Effusive Eruption at Stromboli: New Insights from In Situ and Remote-Sensing Measurements. Remote Sens. 2018, 10, 2035. [CrossRef]

42. Pedersen, G.B.M.; Belart, J.M.C.; Magnússon, E.; Vilmundardóttir, O.K.; Kizel, F.; Sigurmundsson, F.S.; Gísladóttir, G.; Benediktsson, J.A. Hekla volcano, Iceland, in the 20th century: Lava volumes, production rates, and effusion rates. Geophys. Res. Lett. 2018, 45, 1805-1813. [CrossRef]

43. Intrieri, E.; Di Traglia, F.; Del Ventisette, C.; Gigli, G.; Mugnai, F.; Luzi, G.; Casagli, N. Flank instability of Stromboli volcano (Aeolian Islands, Southern Italy): Integration of GB-InSAR and geomorphological observations. Geomorphology 2013, 201, 60-69. [CrossRef] 
44. Calvari, S.; Bonaccorso, A.; Madonia, P.; Neri, M.; Liuzzo, M.; Salerno, G.G.; Behncke, B.; Caltabiano, T.; Cristaldi, A.; Giuffrida, G.; et al. Major eruptive style changes induced by structural modifications of a shallow conduit system: The 2007-2012 Stromboli case. Bull. Volcanol. 2014, 76, 841. [CrossRef]

45. Romagnoli, C.; Kokelaar, P.; Casalbore, D.; Chiocci, F.L. Lateral collapses and active sedimentary processes on the northwestern flank of Stromboli volcano, Italy. Mar. Geol. 2009, 265, 101-119. [CrossRef]

46. Tibaldi, A. Multiple sector collapses at Stromboli volcano, Italy: How they work. Bull. Volcanol. 2001, 63, 112-125. [CrossRef]

47. Di Roberto, A.; Rosi, M.; Bertagnini, A.; Marani, M.P.; Gamberi, F. Distal turbidites and tsunamigenic landslides of Stromboli volcano (Aeolian Islands, Italy). In Submarine Mass Movements and Their Consequences; Springer: Dordrecht, The Netherlands, 2010; pp. 719-731.

48. Kokelaar, P.; Romagnoli, C. Sector collapse, sedimentation and clast population evolution at an active island-arc volcano: Stromboli, Italy. Bull. Volcanol. 1995, 57, 240-262. [CrossRef]

49. Rotonda, T.; Tommasi, P.; Boldini, D. Geomechanical characterization of the volcaniclastic material involved in the 2002 landslides at Stromboli. J. Geotech. Geoenviron. Eng. 2009, 136, 389-401. [CrossRef]

50. Nolesini, T.; Di Traglia, F.; Del Ventisette, C.; Moretti, S.; Casagli, N. Deformations and slope instability on Stromboli volcano: Integration of GBInSAR data and analog modeling. Geomorphology 2013, 180, 242-254. [CrossRef]

51. Calvari, S.; Spampinato, L.; Lodato, L.; Harris, A.J.; Patrick, M.R.; Dehn, J.; Burton, M.; Andronico, D. Chronology and complex volcanic processes during the 2002-2003 flank eruption at Stromboli volcano (Italy) reconstructed from direct observations and surveys with a handheld thermal camera. J. Geophys. Res.: Solid Earth 2005, 110, B02201. [CrossRef]

52. Blackburn, E.A.; Wilson, L.; Sparks, R.J. Mechanisms and dynamics of strombolian activity. J. Geol. Soc. 1976, 132, 429-440. [CrossRef]

53. Coppola, D.; Piscopo, D.; Laiolo, M.; Cigolini, C.; Delle Donne, D.; Ripepe, M. Radiative heat power at Stromboli volcano during 2000-2011: Twelve years of MODIS observations. J. Volcanol. Geotherm. Res. 2012, 215, 48-60. [CrossRef]

54. Di Traglia, F.; Cauchie, L.; Casagli, N.; Saccorotti, G. Decrypting geophysical signals at Stromboli Volcano (Italy): Integration of seismic and Ground-Based InSAR displacement data. Geophys. Res. Lett. 2014, 41, 2753-2761. [CrossRef]

55. Di Traglia, F.; Nolesini, T.; Intrieri, E.; Mugnai, F.; Leva, D.; Rosi, M.; Casagli, N. Review of ten years of volcano deformations recorded by the ground-based InSAR monitoring system at Stromboli volcano: A tool to mitigate volcano flank dynamics and intense volcanic activity. Earth-Sci. Rev. 2014, 139, 317-335. [CrossRef]

56. Di Traglia, F.; Intrieri, E.; Nolesini, T.; Bardi, F.; Del Ventisette, C.; Ferrigno, F.; Frangioni, S.; Frodella, W.; Gigli, G.; Lotti, A.; et al. The Ground-Based InSAR monitoring system at Stromboli volcano: Linking changes in displacement rate and intensity of persistent volcanic activity. Bull. Volcanol. 2014, 76, 786. [CrossRef]

57. Di Traglia, F.; Battaglia, M.; Nolesini, T.; Lagomarsino, D.; Casagli, N. Shifts in the eruptive styles at Stromboli in 2010-2014 revealed by ground-based InSAR data. Sci. Rep. 2015, 5, 13569. [CrossRef] [PubMed]

58. Rizzo, A.L.; Federico, C.; Inguaggiato, S.; Sollami, A.; Tantillo, M.; Vita, F.; Bellomo, S.; Longo, M.; Grassa, F.; Liuzzo, M. The 2014 effusive eruption at Stromboli volcano (Italy): Inferences from soil CO2 flux and 3He/4He ratio in thermal waters. Geophys. Res. Lett. 2015, 42, 2235-2243. [CrossRef]

59. Liotta, M.; Rizzo, A.L.; Barnes, J.D.; D’Auria, L.; Martelli, M.; Bobrowski, N.; Wittmer, J. Chlorine isotope composition of volcanic rocks and gases at Stromboli volcano (Aeolian Islands, Italy): Inferences on magmatic degassing prior to 2014 eruption. J. Volcanol. Geotherm. Res. 2017, 336, 168-178. [CrossRef]

60. Di Traglia, F.; Nolesini, T.; Solari, L.; Ciampalini, A.; Frodella, W.; Steri, D.; Allotta, B.; Rindi, A.; Marini, L.; Monni, N.; et al. Lava delta deformation as a proxy for submarine slope instability. Earth Planet. Sci. Lett. 2018, 488, 46-58. [CrossRef]

61. Giudicepietro, F.; Calvari, S.; Alparone, S.; Bianco, F.; Bonaccorso, A.; Bruno, V.; Caputo, T.; Cristaldi, A.; D'Auria, L.; De Cesare, W.; et al. Integration of Ground-Based Remote-Sensing and In Situ Multidisciplinary Monitoring Data to Analyze the Eruptive Activity of Stromboli Volcano in 2017-2018. Remote Sens. 2019, 11, 1813. [CrossRef] 
62. Di Traglia, F.; Bartolini, S.; Artesi, E.; Nolesini, T.; Ciampalini, A.; Lagomarsino, D.; Martí, J.; Casagli, N. Susceptibility of intrusion-related landslides at volcanic islands: The Stromboli case study. Landslides 2018, 15, 21-29. [CrossRef]

63. Nave, R.; Isaia, R.; Vilardo, G.; Barclay, J. Re-assessing volcanic hazard maps for improving volcanic risk communication: Application to Stromboli Island, Italy. J. Maps 2010, 6, 260-269. [CrossRef]

64. Fornaciai, A.; Favalli, M.; Nannipieri, L. Numerical simulation of the tsunamis generated by the Sciara del Fuoco landslides (Stromboli Island, Italy). Sci. Rep. 2019, 9, 1-12. [CrossRef] [PubMed]

65. Salvatici, T.; Di Roberto, A.; Di Traglia, F.; Bisson, M.; Morelli, S.; Fidolini, F.; Bertagnini, A.; Pompilio, M.; Hungr, O.; Casagli, N. From hot rocks to glowing avalanches: Numerical modelling of gravity-induced pyroclastic density currents and hazard maps at the Stromboli Volcano (Italy). Geomorphology 2016, 273, 93-106. [CrossRef]

66. Zhou, Y.; Parsons, B.; Elliott, J.R.; Barisin, I.; Walker, R.T. Assessing the ability of PLÉIADES stereo imagery to determine height changes in earthquakes: A case study for the El Mayor-Cucapah epicentral area. J. Geophys. Res.: Solid Earth 2015, 120, 8793-8808. [CrossRef]

67. Kolzenburg, S.; Favalli, M.; Fornaciai, A.; Isola, I.; Harris, A.J.L.; Nannipieri, L.; Giordano, D. Rapid updating and improvement of airborne LIDAR DEMs through ground-based SfM 3-D modeling of volcanic features. Ieee Trans. Geosci. Remote Sens. 2016, 54, 6687-6699. [CrossRef]

68. Favalli, M.; Fornaciai, A.; Nannipieri, L.; Harris, A.; Calvari, S.; Lormand, C. UAV-based remote sensing surveys of lava flow fields: A case study from Etna's 1974 channel-fed lava flows. Bull. Volcanol. 2018, 80, 29. [CrossRef]

69. James, F.; Roos, M. MINUIT: A system for function minimization and analysis of the parameter errors and corrections. Comput. Phys. Commun. 1975, 10, 343-367. [CrossRef]

70. Fornaciai, A.; Bisson, M.; Landi, P.; Mazzarini, F.; Pareschi, M.T. A LiDAR survey of Stromboli volcano (Italy): Digital elevation model-based geomorphology and intensity analysis. Int. J. Remote Sens. 2010, 31, 3177-3194. [CrossRef]

71. Favalli, M.; Fornaciai, A. Visualization and comparison of DEM-derived parameters. Application to volcanic areas. Geomorphology 2017, 290, 69-84. [CrossRef]

72. Yokoyama, R.; Shirasawa, M.; Pike, R.J. Visualizing topography by openness: A new application of image processing to digital elevation models. Photogramm. Eng. Remote Sens. 2002, 68, 257-266.

73. Karátson, D.; Yepes, J.; Favalli, M.; Rodríguez-Peces, M.J.; Fornaciai, A. Reconstructing eroded paleovolcanoes on Gran Canaria, Canary Islands, using advanced geomorphometry. Geomorphology 2016, 253, 123-134. [CrossRef]

74. Sofia, G.; Bailly, J.S.; Chehata, N.; Tarolli, P.; Levavasseur, F. Comparison of PLÉIADES and LiDAR digital elevation models for terraces detection in farmlands. Ieee J. Sel. Top. Appl. Earth Obs. Remote Sens. 2016, 9, 1567-1576. [CrossRef]

75. Poli, D.; Remondino, F.; Angiuli, E.; Agugiaro, G. Evaluation of Pléiades-1A triplet on Trento testfield. Int. Arch. Photogramm. Remote Sens. Spat. Inf. Sci. 2013, 1, 287-292. [CrossRef]

76. Serrano, E.; Sanjosé, J.J.; Gómez-Gutiérrez, A.; Gómez-Lende, M. Surface movement and cascade processes on debris cones in temperate high mountain (Picos de Europa, northern Spain). Sci. Total. Environ. 2019, 649, 1323-1337. [CrossRef] [PubMed]

77. Chiocci, F.L.; Romagnoli, C.; Tommasi, P.; Bosman, A. The Stromboli 2002 tsunamigenic submarine slide: Characteristics and possible failure mechanisms. J. Geophys. Res.: Solid Earth 2008, 113, B10102. [CrossRef]

78. Casalbore, D.; Romagnoli, C.; Chiocci, F.; Frezza, V. Morpho-sedimentary characteristics of the volcaniclastic apron around Stromboli volcano (Italy). Mar. Geol. 2010, 269, 132-148. [CrossRef]

79. Casalbore, D.; Romagnoli, C.; Bosman, A.; Chiocci, F.L. Potential tsunamigenic landslides at Stromboli Volcano (Italy): Insight from marine DEM analysis. Geomorphology 2011, 126, 42-50. [CrossRef]

(C) 2020 by the authors. Licensee MDPI, Basel, Switzerland. This article is an open access article distributed under the terms and conditions of the Creative Commons Attribution (CC BY) license (http://creativecommons.org/licenses/by/4.0/). 